Article

\title{
Differential Expression of Nicotine Acetylcholine Receptors Associates with Human Breast Cancer and Mediates Antitumor Activity of $\alpha \mathrm{O}$-Conotoxin GeXIVA
}

\author{
Zhihua Sun $\bowtie$, Manqi Zhangsun, Shuai Dong, Yiqiao Liu, Jiang Qian, Dongting Zhangsun and \\ Sulan Luo *D
}

Key Laboratory of Tropical Biological Resources of Ministry of Education, Key Laboratory for Marine Drugs of Haikou, School of Life and Pharmaceutical Sciences, Hainan University, Haikou 570228, Hainan, China; zhihuasun918@163.com (Z.S.); zhangsunmanqi@163.com (M.Z.); dongshuai_1024@163.com (S.D.);

liuyiqiao.94@foxmail.com (Y.L.); veilness@163.com (J.Q.); zhangsundt@163.com (D.Z.)

* Correspondence: luosulan2003@163.com

Received: 27 December 2019; Accepted: 14 January 2020; Published: 17 January 2020

\begin{abstract}
Nicotinic acetylcholine receptors (nAChRs) are membrane receptors and play a major role in tumorigenesis and cancer progression. Here, we have investigated the differential expression of nAChR subunits in human breast cancer cell lines and breast epithelial cell lines at mRNA and protein levels and the effects of the $\alpha \mathrm{O}$-conotoxin GeXIVA, antagonist of $\alpha 9 \alpha 10 \mathrm{nAChR}$, on human breast cancer cells. Reverse transcription polymerase chain reaction (PCR) demonstrated that all nAChR subunits, except $\alpha 6$, were expressed in the 20 tested cell lines. Real time quantitative PCR (QRT-PCR) suggested that the mRNA of $\alpha 5, \alpha 7, \alpha 9$ and $\beta 4 \mathrm{nAChR}$ subunits were overexpressed in all the breast cancer cell lines compared with the normal epithelial cell line HS578BST. $\alpha 9$ nAChR was highly expressed in almost all the breast cancer cell lines in comparison to normal cells. The different expression is prominent $(p<0.001)$ as determined by flow cytometry and Western blotting, except for MDA-MB-453 and HCC1395 cell lines. $\alpha$ O-conotoxin GeXIVA that targeted $\alpha 9 \alpha 10 \mathrm{nAChR}$ were able to significantly inhibit breast cancer cell proliferation in vitro and merits further investigation as potential agents for targeted therapy.
\end{abstract}

Keywords: nicotinic acetylcholine receptors (nAChRs); Breast cancer cells; $\alpha \mathrm{O}$-conotoxin GeXIVA; anti-proliferation

\section{Introduction}

Cancer is one of the three principal diseases which lead to human mortality and was responsible for 9.6 million deaths worldwide in 2018 [1]. Globally, nearly 1 in 6 deaths is due to cancer (WHO, 2018) [2]. According to the statistics, breast cancer is the second most common carcinoma in the world following lung cancer and also the highest incidence of cancer in women [1]. In China, Chinese cancer registry annual report in 2015 reported that the incidence of breast cancer is still the first vital type of women cancer with an upward trend [3].

Nicotinic acetylcholine receptors (nAChRs), the ligand-activated neurotransmitter receptors in mammals, are divided into muscle and neural nAChRs. The nAChRs are either homomeric or heteromeric pentamers and are comprised of $\alpha$ and non-(alpha) subunits [4-8]. It has been proved that nAChRs are expressed not only in neuronal systems but also in numerous non-neuronal tissues and cells, suggesting that nAChRs may have important roles in other biological processes in addition to synaptic transmission. Further studies showed that nAChRs are related to the development of small-cell 
and non-small-cell lung carcinomas (NSCLCs), head, neck, gastric, pancreatic, gallbladder, liver, colon, breast, cervical, urinary bladder and kidney cancers [8-12]. Several nAChRs subunits, including $\alpha 3, \alpha 7$, $\alpha 9$ and $\beta 4$, are extensively expressed in various tumor cells and they are involved in regulation of cell proliferation, apoptosis, invasion, migration and angiogenesis [13-16]. For instance, previous research showed that suppression of $\alpha 7$-nAChRs by snake $\alpha$-neurotoxins and curare reduced the growth of NSCLC tumor [17,18], Bychkov et al. also confirmed that Ly6/uPAR proteins like Lynx1 retard the cells in G0/1 and G2/M period, inhibit the proliferation and enhance the apoptosis by down-regulating the expression of $\alpha 7$-nAChRs in A549 cells [8]. Furthermore, $\alpha$-conotoxin AuIB could inhibit small-cell lung carcinomas (SCLC) cell viability via $\alpha 3 / \alpha 5 / \beta 4$-containing nAChRs [12]. As for $\alpha 9 \mathrm{nAChRs,} \mathrm{it}$ is important for promoting cancer cell proliferation, angiogenesis, cancer metastasis and apoptosis suppression during carcinogenesis in response to tumor microenvironments $[9,19,20]$. So, nAChR antagonists could potentially be used directly or in combination with established chemotherapeutic drugs to treat related cancers.

As competitive antagonists of nAChRs, $\alpha$-conotoxins ( $\alpha$-Ctxs), have been particularly useful in developing ligands that selectively target one nAChR subtype over another. Some of them have therapeutic potential [21-25]. $\alpha \mathrm{O}$-conotoxin GeXIVA was isolated from Conus generalis, which potently blocks $\alpha 9 \alpha 10 \mathrm{nAChR}$ [26]. In vivo, it also displayed potent alleviation for neuropathic pain in one rat model $[27,28]$. Recently, our research also showed that GeXIVA contributed to the inhibition of cervical cancer cell proliferation [29]. $\alpha \mathrm{O}$-conotoxin GeXIVA have the potential for anticancer treatment both by themselves and in combination with other antitumor drugs.

The present study aimed to detect the differential expression of nAChRs in human breast cancer and human normal breast epithelial cells and the nAChR subunits that may be potential targets for breast cancer, to further evaluates the effects of $\alpha \mathrm{O}$-conotoxin GeXIVA on cellular proliferation.

\section{Results}

\subsection{The LBD cDNA Cloning of Each $n A C h R$ Subunit in Various Human Breast Cell Lines}

Previous studies demonstrated that $\mathrm{nAChRs}$ as ligand-gated ion channels were regulated by binding with acetylcholine (ACh) or nicotinic agonists, such as nicotine and nicotine-containing products [9]. In addition, specific antagonists can block the corresponding different $\mathrm{nAChR}$ subtypes at ligand binding domain (LBD) of the receptor. LBD is the important extracellular area for ligands to interact with receptors [30,31]. The LBD cDNAs of each nAChR subunit in 17 cell lines of various human breast cancer and three normal (nonmalignant) human breast cell lines (MCF-10A, MCF-12A and HS578BST) were amplified by reverse-transcription PCR respectively (Figure 1). Each individual agarose gel electropherogram of each $\mathrm{nAChR}$ subunit was showed in Figure S1.

The LBD cDNAs for $\alpha 3, \alpha 4, \alpha 5, \alpha 7, \alpha 9, \alpha 10, \beta 2, \beta 3$ and $\beta 4$ neuronal-type nAChR subunits were amplified with expected size respectively in all the 17 breast cancer cell lines and the three human normal mammary gland epithelial cell lines (Figure 1). It means the mRNA of all these nAChR subunits are transcribed constitutionally in both breast cancer cells and normal cells. However, 20 cell lines did not produce a specific amplification fragment for $\alpha 6 \mathrm{nAChR}$ subunit's LBD cDNA with the expected size fragments. Therefore, $\alpha 6 \mathrm{nAChR}$ subunit mRNA displayed in specific cell lines without constitutional expression in all the tested breast cells. 


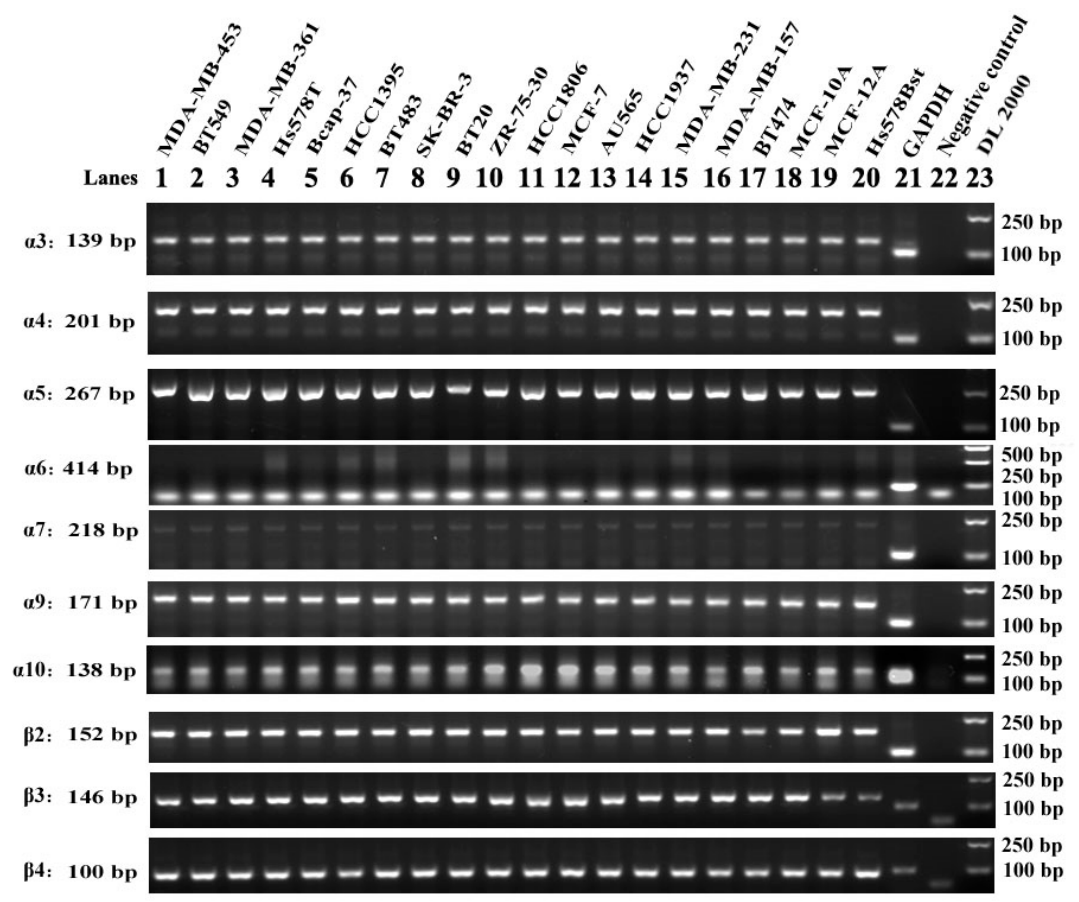

Figure 1. Reverse-transcription polymerase chain reaction (PCR) amplification of neural $n A C h R$ sequences from human breast cancer cells and normal (nonmalignant) breast cells RNA. Agarose gel electrophoresis of PCR products amplified from cultured cells RNA samples reverse-transcribed to cDNA. One microgram of purified total RNA extracted from cultured cells were reverse-transcribed to cDNA and amplified for 30 cycles with ten pairs of $\mathrm{nAChR}$ subtype-specific primers. The size of each amplification product was determined using the DL2000 DNA Marker ladder standard loaded in lane 23. The bands were consistent with the expected sizes, $139 \mathrm{bp}, 201 \mathrm{bp}, 267 \mathrm{bp}, 218 \mathrm{bp}, 171 \mathrm{bp}$, $152 \mathrm{bp}, 146 \mathrm{bp}, 100 \mathrm{bp}$ and $103 \mathrm{bp}$ for the $\alpha 3, \alpha 4, \alpha 5, \alpha 7, \alpha 9, \alpha 10, \beta 2, \beta 3, \beta 4$ neural nAChR subunits (lanes 1 20) and GAPDH (lane 21) respectively, the lane 22 was negative control. Each PCR experiment included one positive control of GAPDH and one negative control of water as template. The negative control could check if the PCR mixture has contamination of other impurity DNA. The positive control of GAPDH gene with a fragment size of $103 \mathrm{bp}$ verified that Reverse-transcription PCR (RT-PCR) was working well, and the synthesized cDNA reverse transcribed from mRNA was completed.

2.2. Quantification and Comparison of Different $n A C h R$ Subunits mRNA in Different Human Breast Cancer and Normal Cell Lines

As described above, all the tested cell lines were found to express neuronal nAChR subunits of $\alpha 3$, $\alpha 4, \alpha 5, \alpha 7, \alpha 9, \alpha 10, \beta 2, \beta 3$ and $\beta 4$. Moreover, previous studies showed that $\mathrm{nAChRs}$ play a crucial role in the course of human cancer development [11,12,32]. In order to quantify and compare the mRNA expression amounts of each $\mathrm{nAChR}$ subunit among human breast cancer cell lines and the normal (nonmalignant) human breast cell lines, real-time quantitative fluorescent PCR were used to detect the mRNA expression level of $\alpha 3, \alpha 4, \alpha 5, \alpha 7, \alpha 9, \alpha 10, \beta 2, \beta 3$ and $\beta 4 \mathrm{nAChR}$ subunits respectively (Figure 2). It is obvious that the mRNAs of $\alpha 5, \alpha 7, \alpha 9$ and $\beta 4 \mathrm{nAChR}$ subunits were overexpressed in all the breast cancer cells, which were much higher than that in the normal cell lines HS578BST (Figure 2C,D,E,I). Other subunits, such as $\alpha 3, \alpha 4, \alpha 10, \beta 2$ and $\beta 3 \mathrm{nAChR}$ had similar mRNA expression level (Figure 2A,B,F-H), which expressed higher in part of breast cancer cells than normal cells.

For $\alpha 5 \mathrm{nAChR}$ subunit (Figure 2C), the highest mRNA expression amount occurred in ZR-75-30 cell line, which had $\sim 400$-fold more than that in normal breast cell line HS578BST. The second highest was HCC1395 cells, which had 230-fold of $\alpha 5 \mathrm{nAChR}$ subunit mRNA more than that in HS578BST cell line. Then expression of MCF-7 cell line had 110-fold more than that in HS578BST. There were seven breast cancer cell lines of MDA-MB-361, BT483, SK-BR-3, BT20, AU565, MDA-MB-231 and MDA-MB-157 with 20 60-fold of $\alpha 5$ subunit mRNA higher than that in the HS578BST. The breast 
cancer cell lines, MDA-MB-453, BT549, HCC1806 and HCC1937 showed 10 20-fold of $\alpha 5$ mRNA higher than that in normal cell line HS578BST. The least $\alpha 5$ mRNA amounts of two breast cancer cell lines, HS578T and Bcap-37 cells had 3-fold more than that in the normal cell line HS578BST, which were statistically significantly different from the normal control.

Compared with normal cell line of HS578BST, $\alpha 7 \mathrm{nAChR}$ subunit had the highest expression level of mRNA in HCC1806 cancer cell line with 600-fold higher than in the normal cell line (Figure 2D). The second highest expression of $\alpha 7$ subunit mRNA was AU565 cancer cells, which had $\sim 120$-fold higher expression than the normal cell line. The third highest expression for $\alpha 7$ subunit mRNA was SK-BR-3 cancer cell line, which showed $\sim 52$-fold higher expression than the normal cell line. The expression of $\alpha 7$ subunit mRNA of cancer cell lines MDA-MB-157 and MCF-7 showed $~ 22-$ fold higher than the normal cell line. The $\alpha 7$ subunit mRNA expression amount of five cancer cell lines that is, BT549, HCC1395, BT20, ZR-75-30 and HCC1937 had more than 15-fold higher expression than the normal cell line. For MDA-MB-453, MDA-MB-361, Bcap-37, BT483 and MDA-MB-361 cancer cell lines, $\alpha 7$ subunit mRNA expression displayed about 2 10-fold higher than its expression in normal cell line (Figure 2D).

For $\alpha 9$ nAChR subunit (Figure 2E), the highest mRNA expression amount occurred in MDA-MB-231, which had 530-fold more than that in the normal breast cell line HS578BST. The second highest was BT549 cells, which had $\sim 300$-fold of $\alpha 9$ nAChR subunit mRNA more than that in the HS578BST. Bcap-37 had $~ 180$-fold of $\alpha 9$ subunit mRNA higher than the normal cell line. ZR-75-30 showed $\sim 147$-fold higher than the normal cell line. The two breast cancer cell lines, HCC1395 and HCC1806 showed $~ 38$-fold of $\alpha 9$ mRNA higher than that of the normal cell line. There were eight breast cancer cell lines, MDA-MB-453, MDA-MB-361, HS578T, BT483, BT20, MCF-7, AU565 and MDA-MB-157 showed 10 20-fold of $\alpha 9$ mRNA higher than its expression in the normal cell line. For breast cancer cell lines SK-BR-3 and HCC1937, $\alpha 9$ subunit mRNA expression displayed $~ 4$-fold higher levels than normal cell line (Figure 2E).

The most significant upregulation for $\beta 4 \mathrm{nAChRs}$ mRNA level was observed in the breast cancer cell line AU565, which had 1500-fold more than the normal cell line HS578BST. There were three breast cancer cell lines, SK-BR-3, HCC1806 and MDA-MB-231 with 120 300-fold of $\beta 4$ subunit mRNA higher than that of the HS578BST. Six breast cancer cell lines, MDA-MB-361, Bcap37, HCC1395, ZR-75-30, MCF-7 and HCC1937 showed 25 60-fold of $\beta 4$ mRNA higher than that of the HS578BST. There was 2 10-fold increase in the amount of $\beta 4$ nAChRs mRNA in MDA-MB-453, BT549, HS578T, BT483, BT20 and MDA-MB-157 cell lines compared to normal cell line HS578BST (Figure 2I).

Compared with human normal mammary gland epithelial cell line HS578BST, there were 14 breast cancer cell lines expressing 2 20-fold higher levels of $\alpha 3$ nAChR subunit, including MDA-MB-453, BT549, HS578T, Bcap-37, HCC1395, BT483, SK-BR-3, BT20, ZR-75-30, HCC1806, AU565, HCC1937, MDA-MB-231 and MDA-MB-157. MDA-MB-361 and MCF-7 did not show significant changes in $\alpha 3$ nAChR expression from cancer cells compared to normal epithelial cells (Figure 2A).

For $\alpha 4$ nAChR subunit (Figure 2B), the highest mRNA expression amount occurred in BT20 cells, which had expression of $\sim 145$-fold higher than normal breast cell line HS578BST. BT483 and HCC1806 showed expression of $\alpha 4$ mRNA 45 50-fold higher than HS578BST. There were ten breast cancer cell lines, including MDA-MB-453, H578T, Bcap37, HCC1395, SK-BR-3, ZR-75-30, MCF-7, AU565, MDA-MB-231 and MDA-MB-157 with expression of $\alpha 4$ subunit mRNA 2 25-fold higher than normal cell line. BT549, MDA-MB-361 and HCC1937 did not have significant changes shown in $\alpha 4$ nAChR expression from cancer cells compared to normal epithelial cells.

The mRNA expression level of $\alpha 10 \mathrm{nAChR}$ subunit in five breast cancer cell lines was similar with the normal cell line respectively, which included MDA-MB-453, BT549, SK-BR-3, ZR-75-30 and HCC1937 (Figure 2F). The other 11 cancer cell lines showed expression of $\alpha 10$ mRNA 2 20-fold higher than the normal cell line, which included MDA-MB-361, HS578T, Bcap37, HCC1395, BT483, BT20, HCC1806, MCF-7, AU565, MDA-MB-231and MDA-MB-157 (Figure 2F). 
Compared to normal cell line HS578BST, there were nine breast cancer cell lines including MDA-MB-453, Bcap37, HCC1395, BT483, BT20, ZR-75-30, HCC1806, MDA-MB-231 and MDA-MB-157 with expression of $\beta 2 \mathrm{nAChR}$ subunit mRNA 4 25-fold higher than HS578BST (Figure 2G). There was no difference in $\beta 2 \mathrm{nAChRs}$ subunit mRNA expression between the normal cell line and the seven breast cancer cell lines, that is, BT549, MDA-MB-361, HS578T, SK-BR-3, MCF-7, AU565 and HCC1937 (Figure 2G).

For $\beta 3 \mathrm{nAChR}$ subunit mRNA expression (Figure $2 \mathrm{H}$ ), there were fourteen breast cancer cell lines with 2 20-fold higher than the normal cell line, which were MDA-MB-453, BT549, HS578T, Bcap37, HCC1395, BT483, SK-BR-3, BT20, ZR-75-30, HCC1806, AU565, HCC1937, MDA-MB-231 and MDA-MB-157. Only MDA-MB-361 and MCF-7 cancer cells had no significant change shown in $\beta 3$ nAChRs expression compared to HS578BST cells.
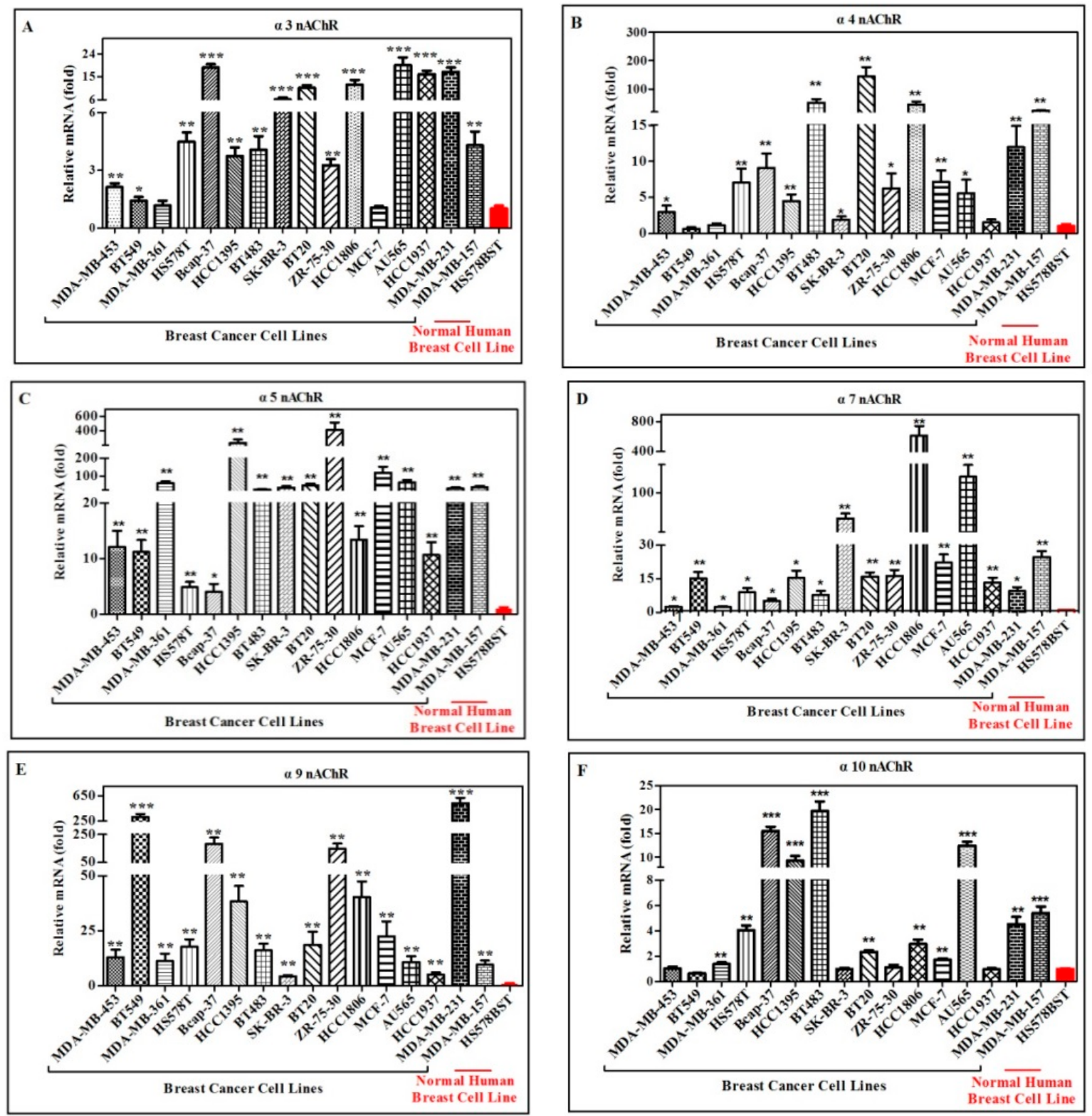

Figure 2. Cont. 

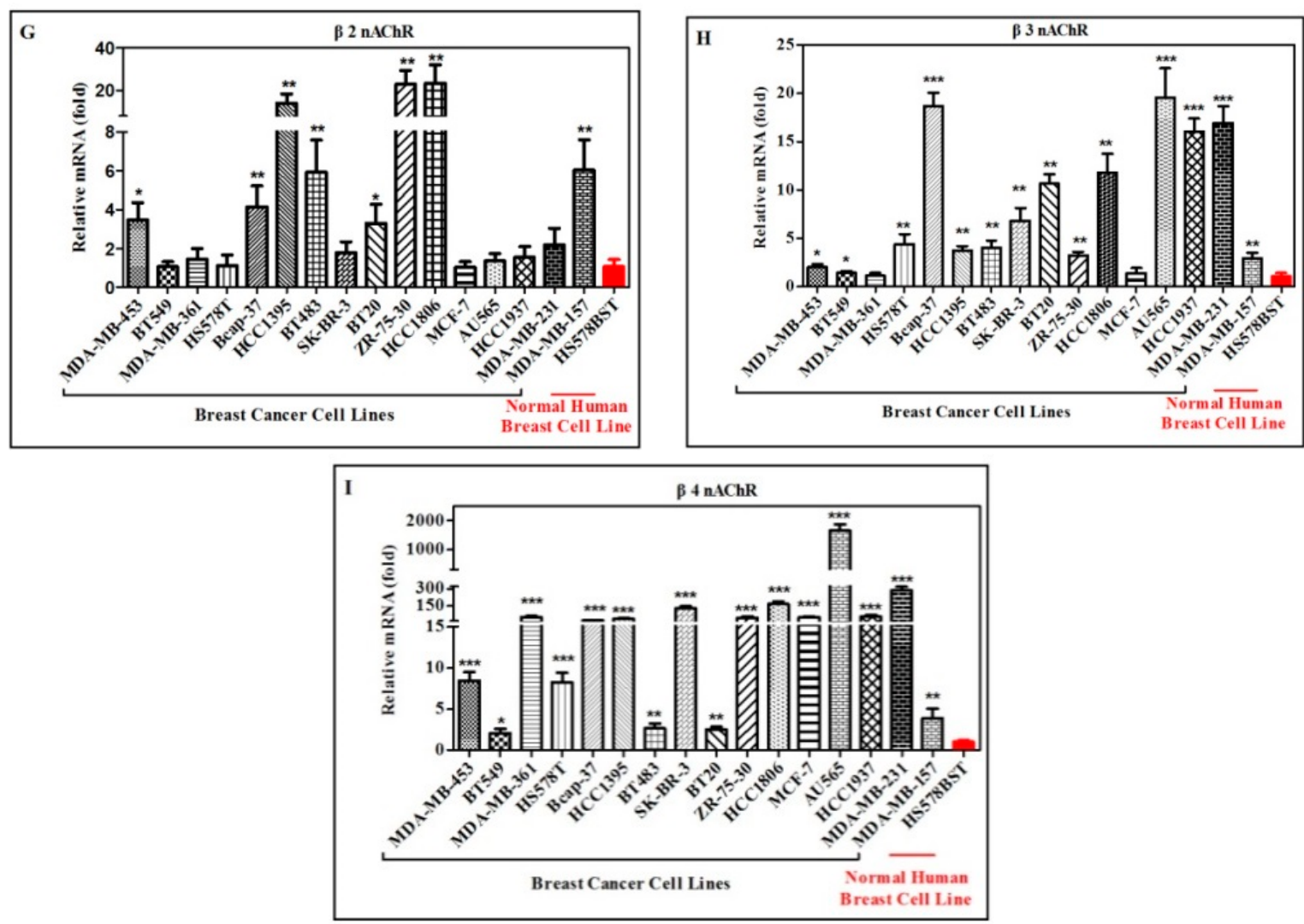

Figure 2. Relative mRNA expression amount of different $n A C h R$ subunits in different human breast cancer cell lines and breast epithelial cell line HS578BST (normal control) detected by real-time PCR. Purified total RNA of each cell line with $1 \mu \mathrm{g}$ was reverse-transcribed to cDNA using poly A primer. Expression level of each $n A C h R$ subunit mRNA was examined by real-time PCR using specific primers for each subunit in all the tested cell lines. (A-I) represent the expression of $\alpha 3, \alpha 4, \alpha 5, \alpha 7, \alpha 9, \alpha 10$, $\beta 2, \beta 3$ and $\beta 4 \mathrm{nAChR}$, respectively. ${ }^{*} p<0.05,{ }^{* *} p<0.01,{ }^{* * *} p<0.001$, breast cancer cells vs. normal cells HS578BST.

It is shown from quantitative PCR results that only four $\mathrm{nAChR}$ subunits that is, $\alpha 5, \alpha 7, \alpha 9$ and $\beta 4 \mathrm{nAChRs}$ are highly expressed in all tested human breast cancer cell lines compared to normal mammary gland epithelial fibrocystic cells (Table 1).

\subsection{The Functional nAChRs Expression on the Surface of Breast Cancer Cells and Mammary Gland Epithelial Cells}

To confirm the protein expression of nAChRs on the cell membrane, samples of the different cell lines were incubated with fluorescently labelled antibody (FITC-conjugated Goat anti-rabbit Ig $(\mathrm{G}+\mathrm{L}))$ and analyzed by flow cytometry (FCM). The specificity of these antibodies was confirmed by Western blotting in some cell lines, such as MCF-7, MAD-MB-157, MDA-MB-231, BT20, SK-BR-3, BT483, HCC1395, MDA-MB-157 $\alpha 9$ KO, HEK-293T, Hela, A549 (Figure S2). Take MDA-MB-157 for example, flow cytometry measurements showed a significant increase in $\alpha 3, \alpha 4, \alpha 5, \alpha 6, \alpha 7, \alpha 9, \alpha 10$, $\beta 2, \beta 3$ and $\beta 4 \mathrm{nAChRs}$ on the surface of breast cancer cells MDA-MB-157 (Figure 3). The difference in mean fluorescence intensity (MFI) for $\alpha 3$ nAChRs between experimental group (MFI 4819) and control group (MFI 115). Likewise, the MFI of $\alpha 4, \alpha 5, \alpha 6, \alpha 7, \alpha 9, \alpha 10, \beta 2, \beta 3, \beta 4 \mathrm{nAChRs}$ is significantly higher in MDA-MB-157 cells and the value were MFI 5077, 1060, 1049, 3704, 3653, 4652, 754, 1578, 4852, respectively (Figure 3A). For MDA-MB-157 cells, all investigated functional nAChRs were expressed on the cell surface but the levels varied between nAChR subunits. $\alpha 3, \alpha 4, \alpha 7, \alpha 9, \alpha 10$ and $\beta 4 \mathrm{nAChRs}$ indicated 32 43-fold difference and $\alpha 5, \alpha 6, \beta 2$ and $\beta 3 \mathrm{nAChRs}$ were $6 \sim 13$-fold difference, all the 
differences had significance (Figure 3B). In addition, protein expression of nAChRs was detected on the all tested cell lines and the results manifested that the nAChRs subunits expressed in all tested cells at protein level (Figure S3). Then, differential expression of each nAChRs was analyzed in different cancer cell lines compared to normal human mammary gland epithelial cells HS578BST (Table 2, Figure S4). It is worth noting that $\alpha 9 \mathrm{nAChRs}$ were highly expressed in almost all the breast cancer cell lines, when compared to normal cells, difference was prominent $(p<0.001)$ except MDA-MB-453 and HCC1395 cell lines (Table 2).

Table 1. Relative expression of nAChR subunits mRNA (fold) in breast cancer cell lines compared with normal cell line HS578BST.

\begin{tabular}{|c|c|c|c|c|c|c|c|c|c|}
\hline \multirow{2}{*}{$\begin{array}{c}\text { Cell Lines } \\
\text { Name }\end{array}$} & \multicolumn{9}{|c|}{ nAChR Subunits } \\
\hline & $\alpha 3$ & $\alpha 4$ & $\alpha 5$ & $\alpha 7$ & $\alpha 9$ & $\alpha 10$ & $\beta 2$ & $\beta 3$ & $\beta 4$ \\
\hline MDA-MB-453 & ++ & + & ++ & + & ++ & $n s$ & ++ & + & +++ \\
\hline BT-549 & + & $n s$ & ++ & ++ & +++ & $n s$ & $n s$ & + & + \\
\hline MDA-MB-361 & $n s$ & $n s$ & ++ & + & ++ & ++ & $n s$ & $n s$ & +++ \\
\hline HS578T & ++ & ++ & + & + & ++ & ++ & $n s$ & ++ & +++ \\
\hline Bcap-37 & ++ & ++ & + & + & ++ & +++ & ++ & +++ & +++ \\
\hline HCC1395 & ++ & ++ & ++ & ++ & ++ & +++ & ++ & ++ & +++ \\
\hline BT-483 & ++ & ++ & ++ & + & ++ & +++ & ++ & ++ & ++ \\
\hline SK-BR-3 & +++ & + & ++ & ++ & ++ & $n s$ & $n s$ & ++ & +++ \\
\hline BT-20 & +++ & ++ & ++ & ++ & ++ & ++ & + & ++ & ++ \\
\hline ZR-75-30 & ++ & + & ++ & ++ & ++ & $n s$ & ++ & ++ & +++ \\
\hline HCC1806 & +++ & ++ & ++ & ++ & ++ & ++ & ++ & ++ & +++ \\
\hline MCF-7 & $n s$ & ++ & ++ & ++ & ++ & ++ & $n s$ & $n s$ & +++ \\
\hline AU565 & +++ & + & ++ & ++ & ++ & +++ & $n s$ & +++ & +++ \\
\hline HCC1937 & +++ & $n s$ & ++ & ++ & + & $n s$ & ns & +++ & +++ \\
\hline MDA-MB-231 & +++ & ++ & ++ & + & +++ & ++ & + & +++ & +++ \\
\hline MDA-MB-157 & ++ & ++ & ++ & ++ & ++ & +++ & ++ & ++ & ++ \\
\hline HS578BST & - & - & - & - & - & - & - & - & - \\
\hline
\end{tabular}

Comparisons of differently expressed of nAChRs in normal control cells (HS578BST) and breast cancer cells. ,+++ and +++ represent upregulation of expression $(p<0.05,0.01$ and 0.001 , respectively); ns represented no significant difference.

$\mathbf{A}$

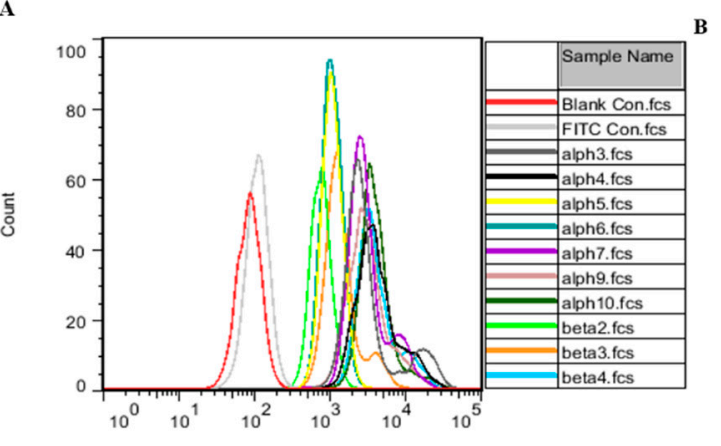

GRN-B-HLog:: Green-B Fluorescence (GRN-B-HLog)

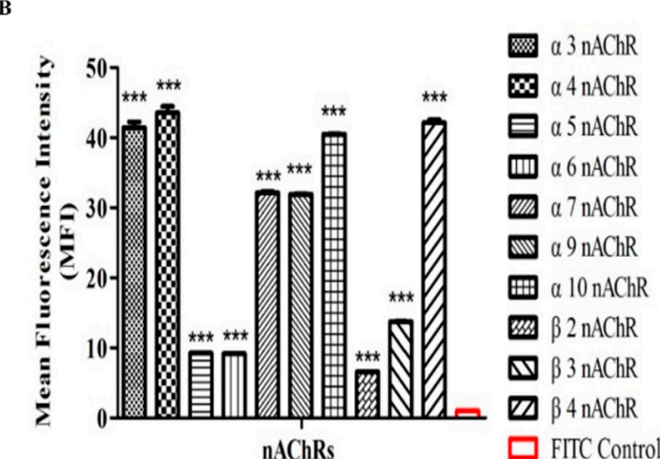

Figure 3. Flow cytometry analysis of $\mathrm{nAChRs}$ staining intensity under antibody treatment. (A) Histograms of cell distribution according to green fluorescence intensity for cell incubated with anti-nAChRs antibodies and FITC-conjugated Goat anti-rabbit Ig $(\mathrm{G}+\mathrm{L})$ are shown. (B) Flow cytometry analysis of functional $\alpha 3, \alpha 4, \alpha 5, \alpha 6, \alpha 7, \alpha 9, \alpha 10, \beta 2, \beta 3$ and $\beta 4 \mathrm{nAChRs}$ expression on the surface of MDA-MB-157 cells. The mean staining intensities of the cells by fluorescently labelled antibody (FITC-conjugated Goat anti-rabbit Ig $(\mathrm{G}+\mathrm{L})$ ) are shown. Data are presented as mean fluorescence intensity $(\mathrm{MFI}) \pm \mathrm{SEM}, n=3,{ }^{* * *} p<0.01$, significantly different from the FITC positive control. Statistical analysis was performed with One-way ANOVA test. 
Table 2. Relative expression of nAChR subunits protein (fold) in breast cancer cell lines compared with normal cell line HS578BST.

\begin{tabular}{ccccccccccc}
\hline Cell Lines & \multicolumn{8}{c}{ nAChR Subunits (Protein Level) } \\
\hline Name & $\alpha \mathbf{3}$ & $\boldsymbol{\alpha} \mathbf{4}$ & $\boldsymbol{\alpha} \mathbf{5}$ & $\boldsymbol{\alpha} \mathbf{6}$ & $\boldsymbol{\alpha} 7$ & $\boldsymbol{\alpha 9}$ & $\boldsymbol{\alpha 1 0}$ & $\boldsymbol{\beta 2}$ & $\boldsymbol{\beta 3}$ & $\boldsymbol{\beta 3 4}$ \\
\hline MDA-MB-453 & $n s$ & $n s$ & $n s$ & $n s$ & $n s$ & $n s$ & $n s$ & $n s$ & $n s$ & $n s$ \\
BT-549 & $n s$ & $n s$ & $n s$ & $n s$ & $n s$ & +++ & $n s$ & $n s$ & $n s$ & $n s$ \\
MDA-MB-361 & $n s$ & + & + & $n s$ & $n s$ & +++ & $n s$ & $n s$ & $n s$ & $n s$ \\
HS578T & $n s$ & $n s$ & $n s$ & $n s$ & $n s$ & +++ & $n s$ & $n s$ & +++ & $n s$ \\
Bcap-37 & $n s$ & $n s$ & $n s$ & $n s$ & $n s$ & +++ & $n s$ & $n s$ & ++ & $n s$ \\
HCC1395 & $n s$ & $n s$ & $n s$ & $n s$ & $n s$ & $n s$ & $n s$ & $n s$ & $n s$ & $n s$ \\
BT-483 & $n s$ & $n s$ & +++ & ++ & + & +++ & $n s$ & $n s$ & +++ & $n s$ \\
SK-BR-3 & $n s$ & + & + & $n s$ & $n s$ & +++ & $n s$ & $n s$ & $n s$ & + \\
BT-20 & $n s$ & ++ & + & + & ++ & +++ & $n s$ & $n s$ & +++ & $n s$ \\
ZR-75-30 & ++ & + & ++ & + & + & +++ & +++ & ++ & $n s$ & ++ \\
HCC1806 & +++ & +++ & +++ & +++ & $n s$ & +++ & ++ & $n s$ & ++ & $n s$ \\
MCF-7 & $n s$ & $n s$ & $n s$ & $n s$ & $n s$ & +++ & ++ & $n s$ & $n s$ & $n s$ \\
AU565 & +++ & +++ & +++ & +++ & +++ & +++ & +++ & ++ & $n s$ & +++ \\
HCC1937 & +++ & $n s$ & $n s$ & $n s$ & $n s$ & +++ & $n s$ & $n s$ & ++ & $n s$ \\
MDA-MB-231 & ++ & ++ & $n s$ & $n s$ & ++ & +++ & $n s$ & $n s$ & $n s$ & ++ \\
MDA-MB-157 & +++ & +++ & ++ & +++ & +++ & +++ & +++ & $n s$ & +++ & +++ \\
BT474 & +++ & $n s$ & ++ & $n s$ & + & +++ & $n s$ & $n s$ & ++ & + \\
HS578BST & - & - & - & & - & - & - & - & - & - \\
\hline
\end{tabular}

Comparisons of differently expressed of nAChRs in normal control cells (HS578BST) and breast cancer cells. ,+++ and +++ represent upregulation of expression $(p<0.05,0.01$ and 0.001 , respectively); ns represented no significant difference.

\subsection{Protein Expression of $\alpha 9$-Containing Subunit $n A C h R$ s in Different Human Breast Cancer Cell Lines}

In our study, the mRNA and protein expression differences for the $\alpha 9 \mathrm{nAChR}$ subunit in different human cancer cell lines have shown in the above results. Thus, further research is warranted to determine the expression differences of $\alpha 9$-containing $\mathrm{nAChR}$ protein in these cell lines by Western blot (Figure 4). Using a specific antibody for the $\alpha 9 \mathrm{nAChR}$ subunit, the total protein content from each cell line was assessed. Expression of $\alpha 9 \mathrm{nAChR}$ protein was seen in all types of the breast cancer cell lines and normal epithelial cells. Comparing with the normal cells HS578BST, the expression levels of $\alpha 9 \mathrm{nAChRs}$ protein were significantly higher in most breast cancer cell lines except for MDA-MB-453, HCC1395 and AU565 cancer cell lines (Figure 4). Among them, ten cancer cell lines, including BT20, BT549, BT474, HS578T, Bcap37, MDA-MB-361, HCC1806, HCC1937, ZR-75-30 and MCF-7 with much higher protein expression level than control which were extremely significantly different from HS578BST $(p<0.01)$. There were three cancer cell lines, BT483, MDA-MB-231 and MDA-MB-157 cell lines that were statistically significant $p<0.05$.

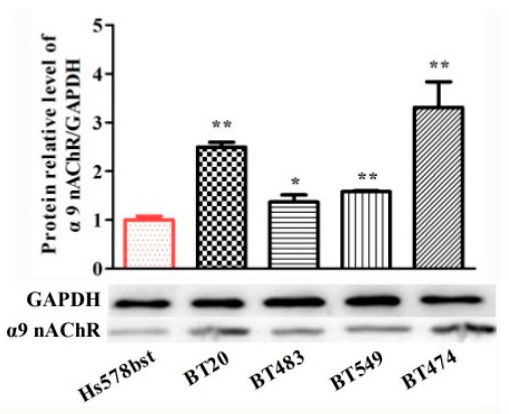

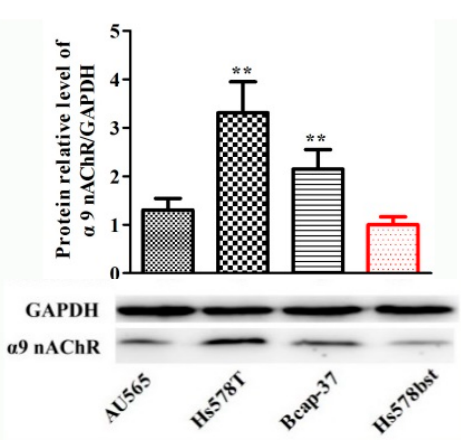

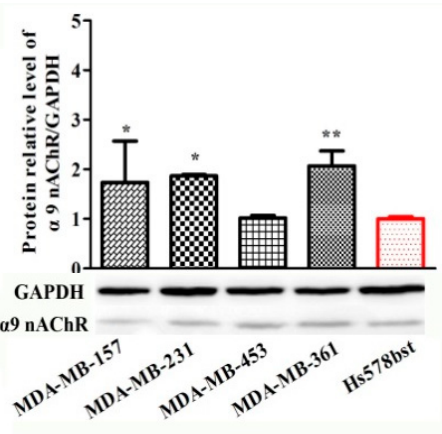

Figure 4. Cont. 

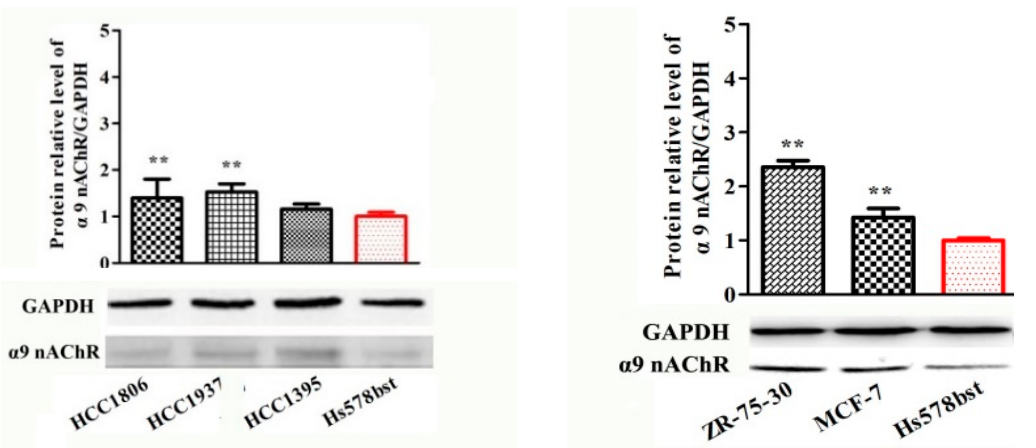

Figure 4. Quantitative analysis of $\alpha 9$-containing $\mathrm{nAChRs}$ by Western blot in various cancer cell lines and breast epithelial cell lines. GAPDH was the control in all experiments. The proteins were detected with the corresponding antibody and an anti-mouse IgG secondary antibody conjugated to horseradish peroxidase (HRP). Each bar is the mean $\pm \mathrm{SD}, n=3 .{ }^{*} p<0.05,{ }^{* *} p<0.01$, breast cancer cell lines vs. breast epithelial cell lines HS578BST (normal cell control).

\section{5. $\alpha O$-Conotoxin GeXIVA Affects Breast Cancer Cell Proliferation through the Inhibition of a9-nAChR-Mediated Signals}

Previous experiments have established that the over-expression of $\alpha 9-n A C h R$ at mRNA and protein level in almost all breast cancer compared to normal epithelial cells HS578BST (Figures 2E, 4 and 5) and $\alpha \mathrm{O}$-conotoxin GeXIVA[1,2] was reported that it is a highly potent and selective antagonist of the $\alpha 9 \alpha 10 \mathrm{nAChRs}$ subtype [26,28]. $\alpha$-conotoxin TxID, a selective antagonist of $\alpha 3 \beta 4 \mathrm{nAChRs,}$ served as control. The peptides were obtained by chemical synthesis and two-step oxidation in our laboratory $[26,28]$.

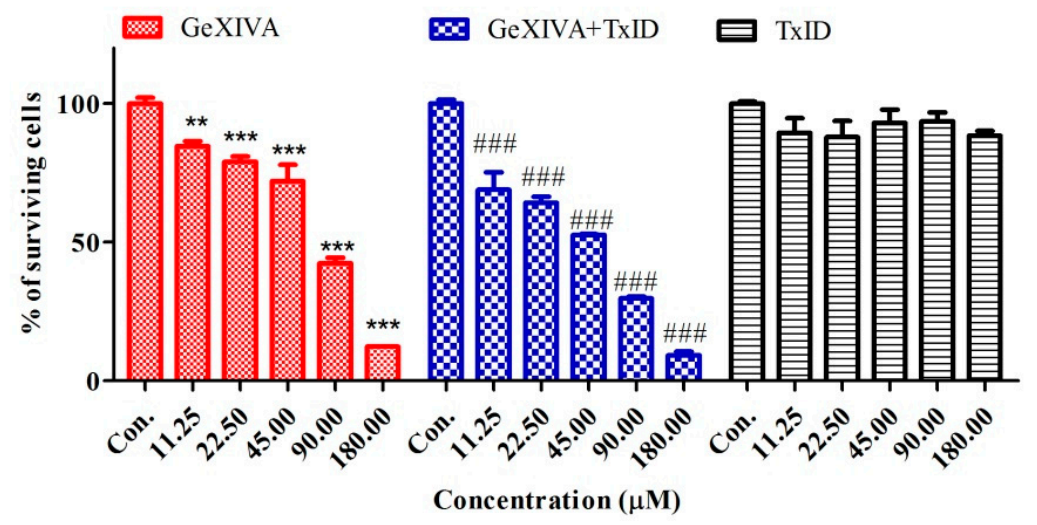

Figure 5. Effects of $\alpha$-conotoxin on the viability of breast cancer cells BT20. The cells were treated with various concentrations of $\alpha$-conotoxin for $24 \mathrm{~h}$. Then, the cell viability was determined by the CCK-8 assay. Values were expressed as mean \pm SD of three independent assays. Statistical analysis was performed with one-way ANOVA. ${ }^{* *} p<0.01,{ }^{* * *} p<0.001$, ${ }^{\# \#} p<0.001$ for significant difference between treatments in comparison to control medium (Con.).

The effects of different treatments on cells proliferation in breast cancer cells were determined by CCK- 8 assay. In breast cancer cells, GeXIVA significantly inhibited the proliferation of cancers (Table 3). Analysis of the data showed that the activity of the GeXIVA was concentration-dependent, on breast cancer cell lines, with EC 50 values ranging from 35 to $130 \mu \mathrm{M}$. However, TxID had no effect on breast cancer cell line BT20. Co-treatment of BT20 cells with GeXIVA and TxID resulted in no significant difference of these cells to GeXIVA. Compared with normal cells treated with the same drug at the same concentration, the inhibition of cancer cells at any concentration of GeXIVA used was significantly higher than that of normal cells. 
Table 3. Dose-effect relationship of $\alpha \mathrm{O}-$ GeXIVA on the breast cancer cells and normal cells ( $24 \mathrm{~h}$ ).

\begin{tabular}{|c|c|c|c|c|c|c|c|}
\hline Treatment & IC $-(1 \mathrm{M})$ & Control & $11.25 \mu \mathrm{M}$ & $22.5 \mu \mathrm{M}$ & $45 \mu \mathrm{M}$ & $90 \mu \mathrm{M}$ & $180 \mu \mathrm{M}$ \\
\hline Cells & & \multicolumn{6}{|c|}{ Mean \pm SD } \\
\hline MDA-MB-157 & 35.18 & $100 \pm 2.82^{d}$ & $72.19 \pm 3.53^{c}$ & $68.14 \pm 2.44^{c}$ & $54.83 \pm 3.27^{b}$ & $51.33 \pm 3.23^{b}$ & $45.37 \pm 2.91^{a}$ \\
\hline MDA-MB-361 & 77.03 & $100 \pm 5.35^{c}$ & $78.58 \pm 6.30^{b}$ & $75.48 \pm 6.82^{b}$ & $70.67 \pm 6.32^{b}$ & $64.57 \pm 6.77^{b}$ & $33.34 \pm 1.84^{a}$ \\
\hline MDA-MB-453 & 65.96 & $100 \pm 4.58^{\mathrm{d}}$ & $93.14 \pm 1.51^{\mathrm{c}}$ & $91.72 \pm 0.58^{c}$ & $81.52 \pm 3.30^{b}$ & $75.41 \pm 4.02^{b}$ & $65.47 \pm 9.63^{a}$ \\
\hline HCC 1395 & 73.50 & $100 \pm 0.80^{\mathrm{f}}$ & $77.79 \pm 0.46^{\mathrm{e}}$ & $73.15 \pm 0.59^{d}$ & $68.21 \pm 1.32^{c}$ & $57.47 \pm 1.75^{b}$ & $49.93 \pm 4.03^{a}$ \\
\hline BT20 & 113.1 & $100 \pm 9.86^{c}$ & $87.15 \pm 5.51^{c}$ & $72.38 \pm 4.73^{b}$ & $69.44 \pm 7.89^{b}$ & $62.18 \pm 4.16^{b}$ & $39.76 \pm 9.75^{a}$ \\
\hline BT474 & 93.63 & $100 \pm 0.47^{\mathrm{e}}$ & $92.98 \pm 0.63^{\mathrm{d}}$ & $91.94 \pm 1.51^{\mathrm{d}}$ & $77.65 \pm 0.62^{c}$ & $23.95 \pm 0.48^{b}$ & $1.51 \pm 0.33^{a}$ \\
\hline BT483 & 103.7 & $100 \pm 4.78^{c}$ & $92.85 \pm 1.58^{c}$ & $92.02 \pm 0.94^{c}$ & $80.73 \pm 3.44^{b}$ & $74.37 \pm 4.19^{b}$ & $63.75 \pm 7.59^{a}$ \\
\hline ВТ549 & 71.08 & $100 \pm 4.22^{d}$ & $73.59 \pm 6.23^{c}$ & $61.09 \pm 2.07^{b}$ & $59.93 \pm 3.01^{b}$ & $53.59 \pm 6.37^{b}$ & $21.90 \pm 2.98^{a}$ \\
\hline SK-BR-3 & 91.16 & $100 \pm 3.75^{d}$ & $84.69 \pm 3.09^{d}$ & $79.04 \pm 3.27^{c}$ & $72.08 \pm 10.11^{c}$ & $42.47 \pm 3.36^{b}$ & $12.37 \pm 0.22^{a}$ \\
\hline Bcap-37 & 78.92 & $100 \pm 2.22^{f}$ & $89.54 \pm 3.70^{e}$ & $80.12 \pm 4.72^{d}$ & $64.51 \pm 3.71^{\mathrm{c}}$ & $47.27 \pm 3.03^{b}$ & $1.42 \pm 0.13^{a}$ \\
\hline MCF-12A & $\sim 246$ & $100 \pm 5.67^{e}$ & $90 \pm 4.72^{\mathrm{d}}$ & $79.49 \pm 4.46^{c}$ & $76.34 \pm 0.71^{b c}$ & $68.71 \pm 3.53^{b}$ & $53.88 \pm 6.01^{a}$ \\
\hline MCF-10A & $\sim 280$ & $100 \pm 3.21^{\mathrm{d}}$ & $89.68 \pm 3.75^{c}$ & $88.82 \pm 2.65^{c}$ & $86.07 \pm 2.70^{c}$ & $72.92 \pm 4.60^{b}$ & $57.90 \pm 5.09^{a}$ \\
\hline HS578BST & $\sim 285$ & $100 \pm 3.42^{c}$ & $99.23 \pm 0.75^{c}$ & $98.26 \pm 1.81^{c}$ & $97.22 \pm 0.18^{c}$ & $92.15 \pm 3.87^{b}$ & $72.30 \pm 3.27^{a}$ \\
\hline
\end{tabular}

The lowercase letters a, b, c, d, e and f represent the 95\% confidence interval. One-way ANOVA was performed on the same row (same cells) and different columns (different concentrations) in the table. It shows that values with same superscript letters in the same line are of no significant difference $(p>0.05)$, those with different letters are of significant or extreme difference $(p<0.05)$.

\section{Discussion}

Recent gene expression profiling studies have categorized breast cancer into four groups including luminal subtypes A and B, HER2+/ER-, Basal-like [32,33] (Table 4). Among them, luminal subtypes A and $\mathrm{B}$ were characterized by higher expression of ER; others were characterized by a lack of expression of ER. There are 20 breast cancer cell lines used in this study, which contain nearly all types of known breast cancer cells so far.

The expression of nAChR subunits has been demonstrated in many non-neuronal cells, including human breast epithelial cells and human breast cancer cells $[19,33,34]$. Previous studies have identified the $\alpha 9 \mathrm{nAChR}$ over-expression in breast cancer relative to normal tissue [19]. The $\alpha 7 \mathrm{nAChRs}$ were also found to be overexpressed in cancer stem cells and breast cancer cells, which activated the signaling pathways downstream and made it to be tractable as potential therapeutic targets for breast cancer $[35,36]$. Chia-Hwa Lee confirmed the expression of $\alpha 5, \alpha 9, \alpha 10 \mathrm{nAChR}$ subtypes in normal breast epithelial cells MCF-10A and malignant MCF-7 breast cells, also presented the importance of $\alpha 9$ nAChRs for nicotine induced transformation of normal mammary gland epithelial cells $[19,33]$. In addition, Mina Kalantari-Dehaghi revealed the expression of genes encoding the neuronal nAChR subunits in MCF-10A and MCF-7 cells, such as $\alpha 3, \alpha 5, \alpha 7, \alpha 9, \alpha 10, \beta 2$ nAChR subunits, which can comprise the $(\alpha 3 / \alpha 6) \beta 2 \pm \alpha 5$ and $\alpha 9 \pm \alpha 10$ ACh-gated ion channels and lead to its involvement in the development of cancer [34]. Interestingly, there is a controversy about the expression of $\alpha 3, \alpha 7, \beta 2, \beta 4$ subunits in the above two cell lines. For instance, Mina Kalantari-Dehaghi [34] viewed $\alpha 3, \alpha 7$ and $\beta 2$ nAChR subunits exist in MCF-10A cells, contrary to Chia-Hwa Lee [19]. But, the primer sequences used by them are almost identical. Their results were not persuasive. We analyzed their primers and found that the specificity of the two primers is not good by National Center for Biotechnology Information (NCBI) primer-blast, which could lead to appearance of both expected and unexpected fragment. Many breast cancer cell lines have not been investigated yet. To address these questions, we redesign the primers for different $n A C h R$ subunits to assay each subunit gene expression level in the 20 cell lines of Table 5. So, this is the first time it is examined each nAChR subunit gene expression (mRNA) in so many (up to 17) breast cancer cell lines and compared with the normal breast cell lines systematically (Table 3). Here it is noteworthy that MCF-10A and MCF-12A cell lines belong to breast 
epithelial cells but they were derived from woman with fibrocystic disease [37], maybe fibrocystic disease relates to the expression of nAChRs. In this study, the breast epithelial cell line HS578BST was used as control.

Twenty cell lines were used in this study, there into three cell lines (SK-BR-3, AU565, MDA-MB-453) belonged to HER2 over-expression subtype. Three cell lines (MCF-7, Bcap-37, ZR-75-30) belonged to Luminal A subtype. Two cell lines (BT-474 and MDA-MB-361) fell within subtype of Luminal B. Twelve cell lines (BT-483, BT-549, BT-20, MDA-MB-231, MDA-MB-157, HCC1395, HCC1937, HCC1806, HS578T, MCF-10A, MCF-12A, HS578BST) fell within the Basal-like subtype. We designed the ten neuronal $\mathrm{nAChR}$ subunits gene specific primers and demonstrated for the first time that normal human mammary glands epithelial cells and mammary cancer cells express the $\alpha 3, \alpha 4, \alpha 5, \alpha 6, \alpha 7, \alpha 9, \alpha 10, \beta 2$, $\beta 3, \beta 4$ neuronal $\mathrm{nAChR}$ subunits and examined the expression level of each subunit. All the existing neuronal nAChR subunits mRNA were analyzed by RT-PCR, which presented in almost all the cell lines except for $\alpha 6 \mathrm{nAChR}$ subunit (Figure 1). But, the protein of $\alpha 6 \mathrm{nAChR}$ was expressed in all cells detected by FCM (Figures S3 and S4). It is suggested that there was difference in genome and protein expression level of $\alpha 6 \mathrm{nAChRs}$ in breast cancer cells. In fact, the details of the relation between mRNA and its encoded protein are not fully clear. The possible reasons for the different expression of the nAChR subunits at two levels include but are not limited to, (1) mRNA stability. In some cases, mRNA degrades rapidly even if it is transcribed, which affects protein expression. (2) A series of powerful and precise regulatory stages, including transcription, post-transcription and translation were involved in Eukaryotic gene expression. Better yet, it is shown from quantitative PCR results that only four nAChR subunits that is, $\alpha 5, \alpha 7, \alpha 9$ and $\beta 4$ are highly expressed in all the tested human breast cancer cell lines comparing to normal mammary gland epithelial fibrocystic cells HS578BST (Table 1). Especially $\alpha 9$ nAChR was confirmed by Western blot and FCM (Table 2, Figure 4). The results of this study confirmed the importance of $\alpha 9$-nAChR for breast cancer cells.

In previous studies, $\alpha 5$ is first considered as an auxiliary subunit that forms functional ion channel of nAChRs only when it is co-expressed with both other $\alpha$-subunits and $\beta$-subunits to a doublet of $\alpha 3$ and either $\beta 2$ or $\beta 4$ modifies the pharmacological and biophysical properties of nAChRs and increases $\mathrm{Ca}^{2+}$ permeability $[9,38]$. Then again, recently, researches revealed that a sudden effect of $\alpha 5$-containing $\mathrm{nAChRs}$ on nicotine intake was linked to lung cancer cell viability, metastasis and invasiveness $[14,39,40] . \alpha 5 \mathrm{nAChRs}$ are expressed in all the tested 16 breast cancer cell lines according to our results, which suggested the importance of $\alpha 5 \mathrm{nAChRs}$ during generation of breast tumors (Table 1). Bychkov et al. and Lyukmanova et al. confirmed that the expression of functional $\alpha 7-n A C h R s$ on the cancer cells membrane by confocal microscopy $[8,11]$, suggesting that the homomeric channels that had been composed of $\alpha 7$ subunits are a valuable therapeutic target for cancers. The main argument was that nicotine activated $\alpha 7 \mathrm{nAChRs}$ can cause $\mathrm{Ca}^{2+}$ influx into cancer cells and trigger membrane depolarization, which activates voltage-gated $\mathrm{Ca}^{2+}$ channels and subsequently activates the MAPK pathway, which may result in inhibition of apoptosis [41,42]. Except for $\alpha 7 \mathrm{nAChRs}$, the homopentameric structure of $\alpha 9 \mathrm{nAChRs}$ has been confirmed to play a major role in breast cancer and other cancer cells $[8,11,19,34]$. Over-expression and activation of the $\alpha 9$-containing nAChRs during tumorigenesis was discovered in human breast epithelial cells. Moreover, $\alpha 9 \mathrm{nAChRs}$ were discovered to be expressed higher in high percentage of advanced-stage (stages 3 and 4) breast cancer tissues than in early stages (stages 1 and 2), which occurred more often in active smoker than in passive smoker (secondhand smoke, involuntary smoking and environmental tobacco smoke) [19]. In this study, the mRNA expression level of $\alpha 9$ nAChRs subunit was much higher in all the tested 16 breast cancer cell lines than the normal cell line (Table 1). Besides, the $\alpha 9$ nAChRs protein on the breast cancer cells surface was more than that on the normal cells with significant difference $(p<0.001)$ except MDA-MB-453 and HCC1395 cell lines (Figure 4, Table 2). Then, a stable MDA-MB-157 breast cancer cell line is established in which $\alpha 9$-nAChR was silenced and we found that the suppression ability of $\alpha \mathrm{O}$-conotoxin GeXIVA is decreased, it is crucial to further identify the role of $\alpha 9 \mathrm{nAChRs}$ in mediating the antitumor activity of $\alpha \mathrm{O}$-Conotoxin GeXIVA. 
As antagonists to nAChRs, neurotoxins are normally used to distinguish between neuronal $\mathrm{nAChRs}$ receptor subunit combinations due to their ability to selectively interact with receptor subtypes [43-46]. A recent research focusing on the antagonists that target nAChRs in the treatment of cancer has provided significant insights into their mechanisms of action. Among these nAChRs, the $\alpha 7$-nAChRs are known to be overexpressed in the SCLC of smokers. In vitro experiments have suggested that cancer cells growth can be inhibited using snake neurotoxins ( $\alpha$-neurotoxins) or snail conotoxins ( $\alpha$-conotoxins). Particularly, it has been found that the presence of $\alpha 7$-nAChR inhibitors, such as methyllylcaconitine and $\alpha$-bungarotoxin, could reverse the pro-angiogenic effects of nicotine and inhibit cancer cell growth. There is moderate evidence suggestive of a critical effect of CHRNA3, CHRNA5 and CHRNB4 expression on SCLC cell viability. $\alpha$-Conotoxin AuIB is derived from the venom of cone snails and blocks $\alpha 3 \beta 4$ nAChRs. Treatment with $\alpha$-conotoxin AuIB led to decreased viability of DMS-53 cells [12,47]. $\alpha$-Conotoxin TxID and its more selective analogues [S9A]TxID and [S9K]TxID is newly-found $\alpha 3 \beta 4 \mathrm{nAChRs}$ antagonist with the potency about 60 -fold higher than AuIB [48-50]. Due to their high specificity and potency on $\alpha 3 \beta 4$ nAChRs, TxID, [S9A] TxID and [S9K] TxID from our lab possess great potential as anticancer agent against $\alpha 3 \beta 4 \mathrm{nAChRs} \mathrm{overexpressing}$ SCLC. Intriguingly, Qian J et al. indicated that the $\alpha 3$ and $\beta 4 \mathrm{nAChRs}$ were upregulated and an antagonist TxID, could inhibit lung cancer cell A549 and NCI-H1299 lines growth [51]. Recently, a series of conotoxins targeting $\alpha 9 \alpha 10 \mathrm{nAChRs}$ were discovered and isolated, such as $\alpha$-conotoxins, Vc1.1, RgIA, It14a and GeXIVA [26,52]. In vivo, $\alpha$-conotoxin Vc1.1 and RgIA, as well as $\alpha \mathrm{O}$-conotoxin GeXIVA displayed potent alleviation of neuropathic pain in rat model $[26,28,53,54]$. With regard to GeXIVA, Luo SL et al. investigated the mechanism of blockade of $\alpha 9 \alpha 10 \mathrm{nAChRs}$ by GeXIVA[1,2] in Xenopus oocytes and analyzed theinteraction between GeXIVA and the $\alpha 9 \alpha 10$ nAChR subtype by molecular modeling [26]. Zhangsun DT et al. further demonstrated that aO-Conotoxin GeXIVA disulfide bond isomers retain potency and selectivity for the human a9a10 subtype [55]. In human cervical cancer cell CaSki and SiHa lines, Liu YQ et al. showed that $\alpha 9$-nAChRs were overexpressed compared with that in normal cells [29]. And GeXIVA revealed obvious inhibition of proliferation and its inhibitory effect on normal cells was also significantly less potent than that on cancer cells [29]. It was also shown that $\alpha 9$-nAChRs can be inhibited by some natural compounds. For instance, only low doses of garcinol $(1 \mathrm{uM})$ from the edible fruit Garciniaindica had inhibited nicotine induced breast cancer cell proliferation through the downregulation of $\alpha 9-\mathrm{nAChR}$ and cyclin D3 expression [35]. Luteolin and quercetin also could inhibit the ability of proliferation by downregulation of the $\alpha 9$-nAChRs expression on cell surface in human breast cancer cells [56]. Tea polyphenol (-)-epigallocatechin-3-gallate have been found to inhibit nicotine-and estrogen-induced $\alpha 9$-nicotinic acetylcholine receptor upregulation in human breast cancer cells and to delay the development of breast cancer cells in vivo [57]. In human cervical cancer cell line CaSki, GeXIVA revealed obvious inhibition of proliferation and its inhibitory effect on normal cells was also significantly less potent than that on cancer cells [29]. In this study, breast cells can be treated with a specific blocker GeXIVA corresponding to $\alpha 9$ nAChRs to further determine the role and significance of these highly expressed $\alpha 9 \mathrm{nAChRs}$ in breast cancer. Although it also inhibited the normal cells, the effect was significantly less than that on cancer cells. Given these findings, $\alpha 9 \alpha 10 \mathrm{nAChRs}$ may be therapeutic targets for breast cancer. Furthermore, $\alpha$-conotoxins from marine cone snails that inhibit $\alpha 9 \alpha 10 \mathrm{nAChRs}$ may provide new clues for breast cancer targeted therapy. 


\section{Materials and Methods}

\subsection{Cell Culture}

The 17 human breast cancer cell lines (Table 4) were purchased from the Kunming Institute of Zoology (Yunnan, China) and American Type Culture Collection (Manassas, VA, USA), which included MDA-MB-157, MDA-MB-231, MDA-MB-361, MDA-MB-453, HCC1395, HCC1937, HCC1806, BT20, BT474, BT483, BT549, HS578T, MCF-7, Bcap-37, SK-BR-3, AU565 and ZR-75-30, the human normal mammary gland epithelial cell lines MCF-10A, MCF-12A and HS578BST. MCF-10A cells were maintained in HuMEC Basal Serum Free Medium supplemented with $10 \mu \mathrm{L} / \mathrm{mL}$ HuMEC Supplement, $50 \mu \mathrm{g} / \mathrm{mL}$ Bovine Pituitary Extract, $200 \mu \mathrm{L} / \mathrm{mL}$ Trypsin/EDTA (Life Technologies, Rockville, MD, USA). MCF-7, SK-BR-3, HS578T, ZR-75-30, BT474, BT483 and HS578BST cells were maintained in Dulbecco's modified eagle medium (DMEM). MDA-MB-231, MDA-MB-453, MDA-MB-157, MDA-MB-361 were maintained in Leibovitz's L-15 Medium. HCC1395, HCC1937, HCC1806, AU565, Bcap-37, BT20, BT-549 were maintained in RPMI 1640. MCF-12A was maintained in EMEM. To make the complete growth medium, all the cell were maintained in base medium, supplemented with fetal bovine serum to a final concentration of $10 \%, 100 \mathrm{U} / \mathrm{mL}$ penicillin and $100 \mathrm{mg} / \mathrm{mL}$ streptomycin at $37^{\circ} \mathrm{C}$ in an atmosphere of $5 \% \mathrm{CO}_{2}$.

\subsection{RNA Isolation and RT-PCR Amplification of Ligand Binding Domain (LBD) of Different Human $n A C h R$ Subunits}

Total RNA of each cell line was isolated using Trizol (Invitrogen, Carlsbad, CA, USA) according to the manufacturer's protocol. The concentration and purity of RNA were determined by NanoDrop 2000 spectrophotometry (Thermo Scientific, Waltham, MA, USA). Equal amounts of RNA (1 $\mu \mathrm{g})$ from each sample were reverse-transcribed into first-strand cDNA with High Capacity cDNA Reverse Transcription Kit (Applied Biosystems, Carlsbad, CA, USA), then the first-strand cDNA subsequently amplified by RT-PCR using specific primers. Based on the reported mRNA sequence of ligand binding domain of human (homo sapiens) nAChR subunits, the specific primers for each subunit were designed (Table 5), which were synthesized by Sangon Biotech Co., Ltd. (Shanghai, China). The target fragment was amplified by polymerase chain reaction (PCR) using the cDNA of each cell line as template.

\subsection{Quantitative Real-Time PCR}

Quantitative real-time PCR (qRT-PCR) was performed using Analytikjena qTOWER3G Real-Time PCR system to amplify various $\mathrm{nAChR}$ subunits in each cell line, including $\alpha 3, \alpha 4, \alpha 5, \alpha 7, \alpha 9, \alpha 10, \beta 2$, $\beta 3$ and $\beta 4 \mathrm{nAChR}$ subunits. Each qPCR reaction mix contained $5 \mu \mathrm{L}$ of SYBR Green I Master (Roche, Indianapolis, USA), $2 \mu \mathrm{M}$ of each primer, $1 \mu \mathrm{L}$ cDNA and DNase and $\mathrm{RNase}$-free $\mathrm{H}_{2} \mathrm{O}$ with total volume of $20 \mu \mathrm{L}$. The cycling conditions were $95^{\circ} \mathrm{C}$ for $10 \mathrm{~min}$ (initial denaturation and polymerase activation) followed by 40 cycles of denaturation at $95^{\circ} \mathrm{C}$ for $15 \mathrm{~s}$, annealing at $58{ }^{\circ} \mathrm{C}$ for $40 \mathrm{~s}$ and extension at $60{ }^{\circ} \mathrm{C}$ for $60 \mathrm{~s}$. To correct minor variations in mRNA extraction and reverse transcription, the gene expression values were normalized using the housekeeping gene glyceraldehyde-3-phosphate dehydrogenase (GAPDH). Relative quantification of the mRNA level was computed by the comparative Ct $\left(2^{-\Delta \Delta \mathrm{Ct}}\right)$ method [58]. The data were analyzed with a sequence detector software (Analytikjena qPCR software 3.2) and $n A C h R$ subunits expression levels in breast cancer cells were compared with those in human normal mammary gland epithelial cell line HS578BST. All tests were performed in triplicate. 
Table 4. Molecular classification of the breast cancer/ normal cells.

\begin{tabular}{|c|c|c|c|c|c|c|}
\hline \multirow{2}{*}{$\begin{array}{l}\text { Cell Lines } \\
\text { Name }\end{array}$} & \multicolumn{4}{|c|}{ Molecular Classification } & \multirow{2}{*}{ Years } & \multirow{2}{*}{ Source and Disease } \\
\hline & Subtypes & ER & PR & HER2 & & \\
\hline MDA-MB-453 & HER2 & & & + & 1976 & Female, 48 years, Caucasian, pericardial effusion, metastatic carcinoma \\
\hline BT-549 & Basal-like & - & - & - & 1978 & Female, 72 years, Caucasian, breast, ductal carcinoma [59] \\
\hline MDA-MB-361 & Luminal B & + & - & + & 1974 & Female, 40 years, Caucasian, brain, adenocarcinoma $[60,61]$ \\
\hline HS578T & Basal-like & - & - & - & 1977 & Female, 74 years, Caucasian, breast, carcinoma [62] \\
\hline Bcap-37 & Luminal A & + & + & - & 1981 & Female, 48 years, Chinese, breast, medullary carcinoma [63] \\
\hline HCC 1395 & Basal-like & - & - & - & 1998 & Female, 43 years, Caucasian, breast/duct, ductal carcinoma $[34,64]$ \\
\hline BT-483 & Basal-like & - & - & - & 1978 & Female, 23 years, Caucasian, breast, ductal carcinoma $[65,66]$ \\
\hline SK-BR-3 & HER2 & - & - & + & 1970 & Female, 43 years, Caucasian, pleural effusion, adenocarcinoma [67] \\
\hline BT-20 & Basal-like & - & - & - & 1958 & Female, 74 years, Caucasian, breast, carcinoma [68] \\
\hline ZR-75-30 & Luminal A & + & + & - & 1978 & Female, 47 years, Black, ascites, ductal carcinoma [69] \\
\hline HCC1806 & Basal-like & - & - & - & 1998 & Female, 60 years, Black, breast, squamous carcinoma $[34,64]$ \\
\hline MCF-7 & Luminal A & + & + & - & 1973 & Female, 69 years, Caucasian, pleural effusion, adenocarcinoma $[59,60,70]$ \\
\hline AU565 & HER2 & - & - & + & 1970 & Female, 43 years, Caucasian, malignant pleural effusion, malignant pleural effusion [67] \\
\hline HCC1937 & Basal-like & - & - & - & 1998 & Female, 23 years, Caucasian, breast/duct, ductal carcinoma $[64,71]$ \\
\hline MDA-MB-231 & Basal-like & - & - & - & 1974 & Female, 51 years, Caucasian, pleural effusion, adenocarcinoma $[60,61]$ \\
\hline MDA-MB-157 & Basal-like & - & - & - & 1972 & Female, 44 years, Black, breast/medulla, medullary carcinoma [72] \\
\hline BT- 474 & Luminal B & + & + & + & 1978 & Female, 60 years, Caucasian, breast/duct, ductal carcinoma $[59,65,66]$ \\
\hline MCF-12A & Normal & & & & 1992 & Female, 60 years, Caucasian, breast, fibrocystic, disease [66] \\
\hline MCA-10A & Normal & & & & 1984 & Female, 36 years, Caucasian, breast, fibrocystic, disease $[37,66]$ \\
\hline HS578BST & Normal & & & & 1977 & Female, 74 years, Caucasian, breast, normal [62] \\
\hline
\end{tabular}

gland epithelial cell lines, others were breast cancer cells. 


\subsection{Protein Extraction and Western Blot Analysis}

The cultured cells were washed with cold phosphate buffer saline (PBS) for three times and harvested using a cell lysis buffer containing protease inhibitors PMSF (Solarbio Life Sciences, Beijing, China). Equal amounts of protein from control and treated cell lysates were separated using a 12.5\% sodium dodecyl sulfate polyacrylamide gel electrophoresis (SDS-PAGE) gel under reducing conditions and transferred onto polyvinylidene fluoride (PVDF) membranes (Solarbio Life Sciences, Beijing, China) that were subsequently probed with primary antibodies (AChR $\alpha 9$, sc-293282, Santa Cruz, CA, USA). In all Western blot experiments, membranes were additionally probed with an antibody for GAPDH (sc-47724, Santa Cruz, CA, USA) to ensure equal loading of protein among samples. Horseradish peroxidase-conjugated secondary antibodies (m-IgGk BP-HRP, sc-516102, Santa Cruz, CA, USA) were used with enhanced chemoluminescence reagent (Biosharp, Guangzhou, China) to visualize the protein bands. Images of the films are captured using the Alpha FluorChem E (ProteinSimple, San Jose, CA, USA).

Table 5. List of the primers and their sequences.

\begin{tabular}{lll}
\hline $\begin{array}{l}\text { Primer Name } \\
\text { (nAChR Subunits) }\end{array}$ & Sequence & Product Size \\
\hline$\alpha 3-\mathrm{F}$ & AACGTGTCTGACCCAGTCATCAT & $139 \mathrm{bp}$ \\
$\alpha 3-\mathrm{R}$ & AGGGGTTCCATTTCAGCTTGTAG & \\
$\alpha 4-\mathrm{F}$ & CGGCAGCCGCCGGATGAC & $201 \mathrm{bp}$ \\
$\alpha 4-\mathrm{R}$ & ATGAAATTCGGCTCCTGGACCTA & \\
$\alpha 5-\mathrm{F}$ & ACTCCACCGGCAAACTACAA & $267 \mathrm{bp}$ \\
$\alpha 5-\mathrm{R}$ & CAGGCGCTTGATTACAAATGA & \\
$\alpha 6-\mathrm{F}$ & GGCCTCTGGACAAGACAA & $414 \mathrm{bp}$ \\
$\alpha 6-\mathrm{R}$ & AAGATTTTCCTGTGTTCCC & \\
$\alpha 7-\mathrm{F}$ & CCACCAACATTTGGCTGCAA & $218 \mathrm{bp}$ \\
$\alpha 7-\mathrm{R}$ & TATGCCTGGAGGCAGGTACT & \\
$\alpha 9-\mathrm{F}$ & TGGCACGATGCCTATCTCAC & $171 \mathrm{bp}$ \\
$\alpha 9-\mathrm{R}$ & TGATCAGCCCATCATACCGC & \multirow{2}{*}{$138 \mathrm{bp}$} \\
$\alpha 10-\mathrm{F}$ & TGACCTCTTTGCCAACTACAC & \\
$\alpha 10-\mathrm{R}$ & CACAGATACAGGGTCAGCAC & $152 \mathrm{bp}$ \\
$\beta 2-\mathrm{F}$ & GGCATGTACGAGGTGTCCTT & \\
$\beta 2-\mathrm{R}$ & ACCAAGTCGATCTCTGTGCG & $146 \mathrm{bp}$ \\
$\beta 3-\mathrm{F}$ & GGTCCGCCCTGTATTACATTC & \\
$\beta 3-\mathrm{R}$ & AGCGTCTAACTTGTGGTCTG & $100 \mathrm{bp}$ \\
$\beta 4-\mathrm{F}$ & TCACAGCTCATCTCCATCAAGCT & \\
$\beta 4-\mathrm{R}$ & CCTGTTTCAGCCAGACATTGGT & $103 \mathrm{bp}$ \\
GAPDH-F & CAGCCTCAAGATCATCAGCA & \\
GAPDH-R & TGTGGTCATGAGTCCTTCCA & \\
\hline
\end{tabular}

\subsection{Flow Cytometry Analysis of Functional nAChRs Expression on the Cell Surface}

A guava easyCyteTM flow cytometer with InCyte software (EMD Millipore, Hayward, CA, USA) was used to validate the presence of the nAChRs. The cultured cells were harvested and washed with PBS for twice, fixed the cells with 4\% PFA for $20 \mathrm{~min}$, washed the cells twice by centrifugation at $1000 \mathrm{rpm}$ for $5 \mathrm{~min}$ each time. Suspend the cells in $0.1 \%$ Triton $\mathrm{X}-100$ in $1 \times$ PBS buffer for $10 \mathrm{~min}$ and washed the cells twice with PBS by centrifugation at $1300 \mathrm{rpm}$ for $5 \mathrm{~min}$ each time. The cells were blocked with 3\% BSA in $1 \times$ PBS for 30 min and then the cells were washed twice with PBS by centrifugation at $1300 \mathrm{rpm}$. Add primary antibody at an appropriate dilution and incubate for $2 \mathrm{~h}$ at room temperature, washed and incubated with secondary antibody (FITC-conjugated Goat anti-rabbit Ig $(G+L))$ for $1 \mathrm{~h}$ at room temperature. Finally, the cells were washed twice and re-suspended in $300 \mu \mathrm{L} 1 \times$ PBS and the expression of nAChRs was analyzed by flow cytometry. The changes of mean fluorescence intensities of each antibody were calculated and it represent the protein expression level of $\mathrm{nAChRs}$ in each cell line. The primary antibodies used were as follows-CHRNA3 
Rabbit Polychonal antibody (10333-1-AP, proteintech, Chicago, IL, USA), anti-Nicotinic Acetylcholine Receptor $\alpha 4$ antibody (ab124832, Abcam, Cambridge, UK), anti-CHRNA5 antibody (A02359-2, Boster, Wuhan, China), CHRNA6 Rabbit Polychonal antibody (11388-1-AP, proteintech, Chicago, IL, USA), anti-CHRNA7 antibody (21379-1-AP, proteintech, Chicago, IL, USA), CHRNA9 Rabbit Polychonal antibody (26025-1-AP, proteintech, Chicago, IL, USA), anti-CHRNA10 antibody (ab234767, Abcam, Cambridge, UK), anti-nicotinic acetylcholine receptor $\beta 2$ antibody (ab55980, Abcam, Cambridge, UK), anti-CHRNB3 antibody (orb338493, biorbyt, Wuhan, China) and CHRNB4 antibody (22192-1-AP, proteintech, Chicago, IL, USA).

\subsection{Cell Viability}

The effect of $\alpha \mathrm{O}$-conotoxin GeXIVA on all tested breast cancer cell lines and normal cells HS578BST proliferation were examined by 2-(2-methoxy-4-nitrophenyl)-3-(4-nitrophenyl)-5-(2,4-disulfo-phenyl)$2 \mathrm{H}$-tetrazolium, monosodium salt (WST-8) assay kit (CCK-8, Solarbio, Beijing, China). Exponentially growth cells were seeded onto 96 -well plates $\left(1 \times 10^{4}\right.$ cells per well $)$ and allowed to grow overnight. The cells were treated with five different concentration of $\alpha \mathrm{O}$-conotoxin GeXIVA $(180 \mu \mathrm{M}, 90 \mu \mathrm{M}$, $45 \mu \mathrm{M}, 22.5 \mu \mathrm{M}$ and $11.25 \mu \mathrm{M}$, respectively). After $24 \mathrm{~h}$, WST- 8 was added into each well for $4 \mathrm{~h}$ before the measurement according to the manufacturer's instruction. The absorbance $450 \mathrm{~nm}$ was measured by a microplate reader (Molecular Devices, SpectraMax M2, San Jose, CA, USA).

\subsection{Statistical Analysis}

Three to five independent repeats were conducted for all experiments. Error bars represent these repeats. Statistical comparisons between groups were performed using ANOVA (Prism GraphPad Software and SPSS 17.0). A Student's $t$-test was used and a $p$-value $<0.05$ was considered significant. Analysis was performed with the SPSS software package (Version 17.0).

\section{Conclusions}

It is well known that the nAChRs are involved in processes of oncogenesis and inflammation. All the compounds mentioned above provided molecular evidence for the possible chemotherapeutic ability of them for smoking-mediated tumorigenesis through nAChRs pathway. Specifically, $\alpha$-conotoxins as a common tool in the studies of nAChRs, which blocked various subtypes of nAChRs selectively and potently. In this article, expression of neuronal $\mathrm{nAChR}$ subunits in each cell line was delineated through different methods, which suggested $\alpha$-conotoxins targeting various $\mathrm{nAChR}$ subtypes may display potent and additional therapeutic effects on related cancers. This study, the high expression of $\alpha 9$-nAChR in cancer cells was correlated with the pathogenesis. Our study has confirmed $\alpha \mathrm{O}$-conotoxin GeXIVA significantly inhibit growth of cancer cells compared with normal cells HS578BST in vitro. Due to its high potency, GeXIVA may possess great potential as anticancer agent for $\alpha 9 \alpha 10 \mathrm{nAChRs}$ overexpressed breast cancer cell lines.

Supplementary Materials: The following are available online at http://www.mdpi.com/1660-3397/18/1/61/s1. Figure S1: Reverse-transcription PCR; Figure S2: The specificity of antibodies; Figure S3: Protein expression by FCM; Figure S4: The difference analysis of protein.

Author Contributions: Z.S. and S.L. designed the experiments; Z.S., Y.L. and J.Q. performed the experiments; Z.S., D.Z. and S.L. analyzed the data; Z.S., M.Z., S.D. and S.L. wrote the manuscript. All authors have read and agree to the published version of the manuscript.

Funding: This work was supported in part by the National Natural Science Foundation of China (No. 81872794 and No. 4196603), the Major Science and Technology Project of Hainan Province (No. ZDKJ2016002) and the Changjiang Scholars and Innovative Research Team in University Grant (IRT_15R15).

Conflicts of Interest: The authors declare no conflict of interest. 


\section{References}

1. Bray, F.; Ferlay, J.; Soerjomataram, I.; Siegel, R.L.; Torre, L.A.; Jemal, A. Global cancer statistics 2018: Globocan estimates of incidence and mortality worldwide for 36 cancers in 185 countries. CA Cancer J. Clin. 2018, 68, 394-424. [PubMed]

2. WHO. Cancer What Is Cancer? Available online: http://www.who.int/cancer/en/ (accessed on 15 January 2020).

3. Wanqing, C.; Rongshou, Z.; Siwei, Z.; Tingting, Z.; Hongmei, Z.; Jie, H. Report of cancer incidence and mortality in China, 2012. China Cancer 2016, 24, 1-7.

4. Schuller, H.M. Is cancer triggered by altered signalling of nicotinic acetylcholine receptors? Nat. Rev. Cancer 2009, 9, 195-205. [CrossRef] [PubMed]

5. Dang, N.; Meng, X.; Song, H. Nicotinic acetylcholine receptors and cancer. Biomed. Rep. 2016, 4, 515-518. [PubMed]

6. Cascio, M. Structure and function of the glycine receptor and related nicotinicoid receptors. J. Biol. Chem. 2004, 279, 19383-19386. [CrossRef] [PubMed]

7. Albuquerque, E.X.; Pereira, E.F.R.; Manickavasagom, A.; Rogers, S.W. Mammalian nicotinic acetylcholine receptors: From structure to function. Physiol. Rev. 2009, 89, 73-120. [PubMed]

8. Bychkov, M.; Shenkarev, Z.; Shulepko, M.; Shlepova, O.; Kirpichnikov, M.; Lyukmanova, E. Water-Soluble variant of human Lynx1 induces cell cycle arrest and apoptosis in lung cancer cells via modulation of alpha7 nicotinic acetylcholine receptors. PLoS ONE 2019, 14, e0217339. [CrossRef]

9. Grando, S.A. Connections of nicotine to cancer. Nat. Rev. Cancer 2014, 14, 419-429. [CrossRef]

10. Scherl, C.; SchãFer, R.; Schlabrakowski, A.; Tziridis, K.; Iro, H.; Wendler, O. Nicotinic acetylcholine receptors in head and neck cancer and their correlation to tumor site and progression. ORL J. Otorhinolaryngol. Relat. Spec. 2016, 78, 151-158. [CrossRef]

11. Lyukmanova, E.N.; Bychkov, M.L.; Sharonov, G.V.; Efremenko, A.V.; Shulepko, M.A.; Kulbatskii, D.S.; Shenkarev, Z.O.; Feofanov, A.V.; Dolgikh, D.A.; Kirpichnikov, M.P. Human secreted proteins SLURP-1 and SLURP-2 control the growth of epithelial cancer cells via interactions with nicotinic acetylcholine receptors. Br. J. Pharmacol. 2018, 175, 1973-1986.

12. Improgo, M.R.; Soll, L.G.; Tapper, A.R.; Gardner, P.D. Nicotinic acetylcholine receptors mediate lung cancer growth. Front. Physiol. 2013, 4, 251. [CrossRef] [PubMed]

13. Robert, Z.; Małgorzata, K.; Dominika, U.; Aneta, L.; Sławomir, L. Role of $\alpha 7$ nicotinic receptor in the immune system and intracellular signaling pathways. Cent. Eur. J. Immunol. 2015, 40, 373-379.

14. Sun, H.; Ma, X. $\alpha 5$-nAChR modulates nicotine-induced cell migration and invasion in A549 lung cancer cells. Exp. Toxicol. Pathol. 2015, 67, 477-482. [CrossRef] [PubMed]

15. Ho, Y.S.; Lee, C.H.; Wu, C.H. The Alpha 9-Nicotinic Acetylcholine Receptor Serves as a Molecular Target for Breast Cancer Therapy. J. Exp. Clin. Med. 2011, 3, 246-251. [CrossRef]

16. Calleja-Macias, I.E.; Kalantari, M.; Bernard, H.U. Cholinergic signaling through nicotinic acetylcholine receptors stimulates the proliferation of cervical cancer cells: An explanation for the molecular role of tobacco smoking in cervical carcinogenesis? Int. J. Cancer 2009, 124, 1090-1096. [CrossRef]

17. Grozio, A.; Paleari, L.; Catassi, A.; Servent, D.; Cilli, M.; Piccardi, F.; Paganuzzi, M.; Cesario, A.; Granone, P.; Mourier, G. Natural agents targeting the alpha7-nicotinic-receptor in NSCLC: A promising prospective in anti-cancer drug development. Int. J. Cancer 2010, 122, 1911-1915. [CrossRef]

18. Zhang, C.; Ding, X.; Zhao, Q.; Yang, X.; An, S.; Wang, H.; Xu, L.; Zhu, L.; Chen, H. Role of $\alpha 7-$ nicotinic acetylcholine receptor in nicotine-induced invasion and epithelial-to-mesenchymal transition in human non-small cell lung cancer cells. Oncotarget 2016, 7, 59199-59208.

19. Lee, C.H.; Huang, C.S.; Chen, C.S.; Tu, S.H.; Wang, Y.J.; Chang, Y.J.; Tam, K.W.; Wei, P.L.; Cheng, T.C.; Chu, J.S. Overexpression and activation of the $\alpha 9$-nicotinic receptor during tumorigenesis in human breast epithelial cells. J. Natl. Cancer Inst. 2010, 102, 1322-1335. [CrossRef]

20. Huang, L.C.; Lin, C.L.; Qiu, J.Z.; Lin, C.Y.; Hsu, K.W.; Tam, K.W.; Lee, J.Y.; Yang, J.M.; Lee, C.H. Nicotinic acetylcholine receptor subtype alpha-9 mediates triple-negative breast cancers based on a spontaneous pulmonary metastasis mouse model. Front. Cell. Neurosci. 2017, 11, 336. [CrossRef]

21. Giribaldi, J.; Dutertre, S. $\alpha$-Conotoxins to explore the molecular, physiological and pathophysiological functions of neuronal nicotinic acetylcholine receptors. Neurosci. Lett. 2017, 679, 24-34. [CrossRef] 
22. Hone, A.J.; Mcintosh, J.M.; Azam, L.; Lindstrom, J.; Lucero, L.; Whiteaker, P.; Passas, J.; Blã, Z.J.; Albillos, A. $\alpha$-conotoxins identify the $\alpha 3 \beta 4^{*}$ subtype as the predominant nicotinic acetylcholine receptor expressed in human adrenal chromaffin cells. Mol. Pharmacol. 2015, 88, 881-893. [CrossRef] [PubMed]

23. Hannon, H.; Atchison, W. Omega-conotoxins as experimental tools and therapeutics in pain management. Mar. Drugs 2013, 11, 680-699. [CrossRef] [PubMed]

24. Essack, M.; Bajic, V.B.; Archer, J.A.C. Conotoxins that confer therapeutic possibilities. Mar. Drugs 2012, 10, 1244-1265. [CrossRef] [PubMed]

25. Richard, L.; McIntosh, J. Conotoxins: Therapeutic potential and application. Mar. Drugs 2006, 4, 119-142.

26. Luo, S.; Zhangsun, D.; Harvey, P.J.; Kaas, Q.; Wu, Y.; Zhu, X.; Hu, Y.; Li, X.; Tsetlin, V.I.; Christensen, S.; et al. Cloning, synthesis and characterization of $\alpha \mathrm{O}$-conotoxin GeXIVA, a potent $\alpha 9 \alpha 10$ nicotinic acetylcholine receptor antagonist. Proc. Natl. Acad. Sci. USA 2015, 112, E4026-E4035. [CrossRef]

27. Wang, H.; Li, X.D.; Zhangsun, D.; Yu, G.; Su, R.; Luo, S. The alpha9alpha10 nicotinic acetylcholine receptor antagonist alpha O-conotoxin GeXIVA[1,2] alleviates and reverses chemotherapy-induced neuropathic pain. Mar. Drugs 2019, 17, 265. [CrossRef]

28. Li, X.; Hu, Y.; Wu, Y.; Huang, Y.; Yu, S.; Ding, Q.; Zhangsun, D.; Luo, S. Anti-hypersensitive effect of intramuscular administration of $\alpha \mathrm{O}$-conotoxin GeXIVA[1,2] and GeXIVA[1,4] in rats of neuropathic pain. Prog. Neuropsychopharmacol. Biol. Psychiatry 2016, 66, 112-119. [CrossRef]

29. Liu, Y.; Qian, J.; Sun, Z.; Zhangsun, D.; Luo, S. Cervical cancer correlates with the differential expression of nicotinic acetylcholine receptors and reveals therapeutic targets. Mar. Drugs 2019, 17, 256. [CrossRef]

30. Li, S.X.; Huang, S.; Bren, N.; Noridomi, K.; Dellisanti, C.D.; Sine, S.M.; Chen, L. Ligand-binding domain of an $\alpha 7-$ nicotinic receptor chimera and its complex with agonist. Nat. Neurosci. 2011, 14, 1253-1259. [CrossRef]

31. Morales-Perez, C.L.; Noviello, C.M.; Hibbs, R.E. X-ray structure of the human alpha4beta2 nicotinic receptor. Nature 2016, 538, 411-415. [CrossRef]

32. Zhao, Y. The oncogenic functions of nicotinic acetylcholine receptors. J. Oncol. 2016, 2016, 9650481. [CrossRef] [PubMed]

33. Lee, C.H.; Chang, Y.C.; Chen, C.S.; Tu, S.H.; Wang, Y.J.; Chen, L.C.; Chang, Y.J.; Wei, P.L.; Chang, H.W.; Chang, C.H. Crosstalk between nicotine and estrogen-induced estrogen receptor activation induces $\alpha 9$-nicotinic acetylcholine receptor expression in human breast cancer cells. Breast Cancer Res. Treat. 2011, 129, 331-345. [CrossRef] [PubMed]

34. Kalantari-Dehaghi, M.; Parnell, E.A.; Armand, T.; Bernard, H.-U.; Grando, S.A. The nicotinic acetylcholine receptor-mediated reciprocal effects of the tobacco nitrosamine NNK and SLURP-1 on human mammary epithelial cells. Int. Immunopharmacol. 2015, 29, 99-104. [CrossRef] [PubMed]

35. Chen, C.S.; Lee, C.H.; Hsieh, C.D.; Ho, C.T.; Pan, M.H.; Huang, C.S.; Tu, S.H.; Wang, Y.J.; Chen, L.C.; Chang, Y.J. Nicotine-induced human breast cancer cell proliferation attenuated by garcinol through down-regulation of the nicotinic receptor and cyclin D3 proteins. Breast Cancer Res. Treat. 2011, 125, 73-87. [CrossRef] [PubMed]

36. Lin, W.; Hirata, N.; Sekino, Y.; Kanda, Y. Role of $\alpha 7$-nicotinic acetylcholine receptor in normal and cancer stem cells. Curr. Drug Targets 2012, 13, 656-665. [PubMed]

37. Tait, L.; Soule, H.D.; Russo, J. Ultrastructural and immunocytochemical characterization of an immortalized human breast epithelial cell line, MCF-10. Cancer Res. 1990, 50, 6087-6094. [PubMed]

38. Gerzanich, V.; Wang, F.; Kuryatov, A.; Lindstrom, J. alpha 5 subunit alters desensitization, pharmacology, $\mathrm{Ca}^{++}$permeability and $\mathrm{Ca}^{++}$modulation of human neuronal alpha 3 nicotinic receptors. J. Pharmacol. Exp. Ther. 1998, 286, 311-320.

39. Wojaskrawczyk, K.; Krawczyk, P.; Biernacka, B.; Grzybek, M.; Kołodziej, P.; Kucharczyk, T.; Mlak, R.; Milanowski, J. The polymorphism of the CHRNA5 gene and the strength of nicotine addiction in lung cancer and COPD patients. Eur. J. Cancer Prev. 2012, 21, 111-117. [CrossRef]

40. Ma, X.; Jia, Y.; Zu, S.; Li, R.; Jia, Y.; Zhao, Y.; Xiao, D.; Dang, N.; Wang, Y. $\alpha 5$ nicotinic acetylcholine receptor mediates nicotine-induced HIF- $1 \alpha$ and VEGF expression in non-small cell lung cancer. Toxicol. Appl. Pharmacol. 2014, 278, 172-179. [CrossRef]

41. Sandeep, S.; Smitha, P.; Srikumar, C. Nicotinic acetylcholine receptor signaling in tumor growth and metastasis. J. Oncol. 2011, 2011, 456743.

42. Gankhuyag, N.; Lee, K.-H.; Cho, J.-Y. The role of nitrosamine (NNk) in breast cancer carcinogenesis. J. Mammary Gland Biol. Neoplasia 2017, 22, 159-170. [CrossRef] [PubMed] 
43. Thapa, P.; Espiritu, M.J.; Cabalteja, C.; Bingham, J.P. The emergence of cyclic peptides: The potential of bioengineered peptide drugs. Int. J. Pept. Res. Ther. 2014, 20, 545-551. [CrossRef]

44. Luetje, C.W.; Wada, K.; Rogers, S.; Abramson, S.N.; Tsuji, K.; Heinemann, S.; Patrick, J. Neurotoxins distinguish between different neuronal nicotinic acetylcholine receptor subunit combinations. J. Neurochem. 1990, 55, 632-640. [CrossRef] [PubMed]

45. Hung, C.S.; Peng, Y.J.; Wei, P.L.; Lee, C.H.; Su, H.Y.; Ho, Y.S.; Lin, S.Y.; Wu, C.H.; Chang, Y.J. The alpha9 nicotinic acetylcholine receptor is the key mediator in nicotine-enhanced cancer metastasis in breast cancer cells. J. Exp. Clin. Med. 2011, 3, 283-292. [CrossRef]

46. Eline, L.; Steve, P.; Isuru, W.; Jan, T. Conotoxins targeting nicotinic acetylcholine receptors: An overview. Mar. Drugs 2014, 12, 2970-3004.

47. Azam, L.; Mcintosh, J.M. $\alpha$-Conotoxins as pharmacological probes of nicotinic acetylcholine receptors. Acta Pharmacol. Sin. 2009, 30, 771-783. [CrossRef]

48. Luo, S.; Zhangsun, D.; Zhu, X.; Wu, Y.; Hu, Y.; Christensen, S.; Harvey, P.J.; Akcan, M.; Craik, D.J.; Mcintosh, J.M. Characterization of a novel alpha-conotoxin TxID from conus textile that potently blocks rat alpha3beta4 nicotinic acetylcholine receptors. J. Med. Chem. 2013, 56, 9655-9663. [CrossRef] [PubMed]

49. Wu, Y.; Zhangsun, D.; Zhu, X.; Kaas, Q.; Zhangsun, M.; Harvey, P.J.; Craik, D.J.; Mcintosh, J.M.; Luo, S. $\alpha$-Conotoxin [S9A]TxID potently discriminates between $\alpha 3 \beta 4$ and $\alpha 6 / \alpha 3 \beta 4$ nicotinic acetylcholine receptors. J. Med. Chem. 2017, 60, 5826-5833. [CrossRef] [PubMed]

50. Yu, J.; Zhu, X.; Harvey, P.J.; Kaas, Q.; Zhangsun, D.; Craik, D.J.; Luo, S. Single amino acid substitution in alpha-conotoxin TxID reveals a specific alpha3beta4 nicotinic acetylcholine receptor antagonist. J. Med. Chem. 2018, 61, 9256-9265. [CrossRef]

51. Qian, J.; Liu, Y.-Q.; Sun, Z.-H.; Zhangsun, D.-T.; Luo, S.-L. Identification of nicotinic acetylcholine receptor subunits in different lung cancer cell lines and the inhibitory effect of alpha-conotoxin TxID on lung cancer cell growth. Eur. J. Pharmacol. 2019, 865, 172674. [CrossRef]

52. Peng, C.; Tang, S.; Pi, C.; Liu, J.; Wang, F.; Wang, L.; Zhou, W.; Xu, A. Discovery of a novel class of conotoxin from conus litteratus, lt14a, with a unique cysteine pattern. Peptides 2006, 27, 2174-2181. [CrossRef] [PubMed]

53. Vincler, M.; Wittenauer, S.; Parker, R.; Ellison, M.; Olivera, B.M.; McIntosh, J.M. Molecular mechanism for analgesia involving specific antagonism of $\alpha 9 \alpha 10$ nicotinic acetylcholine receptors. Proc. Natl. Acad. Sci. USA 2006, 103, 17880-17884. [CrossRef] [PubMed]

54. Mannelli, L.D.C.; Cinci, L.; Micheli, L.; Zanardelli, M.; Pacini, A.; Mcintosh, J.M.; Ghelardini, C. $\alpha$-Conotoxin RgIA protects against the development of nerve injury-induced chronic pain and prevents both neuronal and glial derangement. Pain 2014, 155, 1986-1995. [CrossRef] [PubMed]

55. Zhangsun, D.; Zhu, X.; Kaas, Q.; Wu, Y.; Craik, D.J.; McIntosh, J.M.; Luo, S. $\alpha$ O-Conotoxin GeXIVA disulfide bond isomers exhibit differential sensitivity for various nicotinic acetylcholine receptors but retain potency and selectivity for the human $\alpha 9 \alpha 10$ subtype. Neuropharmacology 2017, 127, 243-252. [CrossRef] [PubMed]

56. Yungleun, S.; Liu, H.C.; Chen, C.S.; Chunghuei, H.; Pan, M.H.; Chang, H.W.; Chang, C.H.; Chen, F.C.; Chitang, H.; Yang, Y.Y. Combination treatment with luteolin and quercetin enhances antiproliferative effects in nicotine-treated MDA-MB-231 cells by down-regulating nicotinic acetylcholine receptors. J. Agric. Food Chem. 2010, 58, 235-241.

57. Tu, S.H.; Ku, C.Y.; Ho, C.T.; Chen, C.S.; Huang, C.S.; Lee, C.H.; Chen, L.C.; Pan, M.H.; Chang, H.W.; Chang, C.H. Tea polyphenol (-)-epigallocatechin-3-gallate inhibits nicotine- and estrogen-induced $\alpha 9$-nicotinic acetylcholine receptor upregulation in human breast cancer cells. Mol. Nutr. Food Res. 2015, 55, 455-466. [CrossRef]

58. Bubner, B.; Baldwin, I.T. Use of real-time PCR for determining copy number and zygosity in transgenic plants. Plant Cell Rep. 2004, 23, 263-271. [CrossRef]

59. Katchman, B.A.; Ocal, I.T.; Cunliffe, H.E.; Chang, Y.H.; Hostetter, G.; Watanabe, A.; Lobello, J.; Lake, D.F. Expression of quiescin sulfhydryl oxidase 1 is associated with a highly invasive phenotype and correlates with a poor prognosis in Luminal B breast cancer. Breast Cancer Res. 2013, 15, R28. [CrossRef]

60. Yousef, E.M.; Laperrière, D.; Ramzan-Tahir, M.; Mader, S.; Gaboury, L.A. Deregulated expression of ANXA1 in human high-grade breast cancers. J. Mol. Biomark. Diagn. 2003, 4, 2.

61. Cailleau, R.; Young, R.; Olivé, M.; Reeves, J.R.W. Breast tumor cell lines from pleural effusions. J. Natl. Cancer Inst. 1974, 53, 661-674. [CrossRef] 
62. Hackett, A.J.; Smith, H.S.; Springer, E.L.; Owens, R.B.; Nelsonrees, W.A.; Riggs, J.L.; Gardner, M.B. Two syngeneic cell lines from human breast tissue: The aneuploid mammary epithelial (Hs578t) and the diploid myoepithelial (Hs578bst) cell lines. J. Natl. Cancer Inst. 1977, 58, 1795-1806. [CrossRef] [PubMed]

63. Chen, C.W.; Zhang, J.Q.; Wang, S.X. Establishment and investigation biological functions of breast cancer cell lines Bcap-37. J. Peking Univ. (Med. Ed.) 1983, 15, 161-164.

64. Gazdar, A.; Kurvari, V.; Virmani, A.; Gollahon, L.; Sakaguchi, M.; Westerfield, M.; Kodagoda, D.; Stasny, V.; Cunningham, H.; Wistuba, I. Characterization of paired tumor and non-tumor cell lines established from patients with breast cancer. Int. J. Cancer 2015, 78, 766-774. [CrossRef]

65. Lasfargues, E.Y.; Coutinho, W.G.; Redfield, E.S. Isolation of two human tumor epithelial cell lines from solid breast carcinomas. J. Natl. Cancer Inst. 1978, 61, 967-978.

66. Subik, K.; Lee, J.F.; Baxter, L.; Strzepek, T.; Costello, D.; Crowley, P.; Xing, L.; Hung, M.C.; Bonfiglio, T.; Hicks, D.G. The expression patterns of ER, PR, HER2, CK5/6, EGFR, Ki-67 and AR by immunohistochemical analysis in breast cancer cell lines. Breast Cancer Basic Clin. Res. 2010, 4, 35-41. [CrossRef]

67. Trempe, G.L. Human breast cancer in culture. Recent Results Cancer Res. 1976, 57, 33-41.

68. Lasfargues, E.Y.; Ozzello, L. Cultivation of human breast carcinomas. J. Natl. Cancer Inst. 1958, 21, $1131-1147$.

69. Engel, L.W.; Young, N.A.; Tralka, T.S.; Lippman, M.E.; O’Brien, S.J.; Joyce, M.J. Establishment and characterization of three new continuous cell lines derived from human breast carcinomas. Cancer Res. 1978, $38,3352-3364$.

70. Soule, H.D.; Vazquez, J.; Long, A.; Albert, S.; Brennan, M. A human cell line from a pleural effusion derived from a breast carcinoma. J. Natl. Cancer Inst. 1973, 51, 1409-1416. [CrossRef]

71. Tomlinson, G.E.; Chen, T.T.; Stastny, V.A.; Virmani, A.K.; Spillman, M.A.; Tonk, V.; Blum, J.L.; Schneider, N.R.; Wistuba, I.I.; Shay, J.W.; et al. Characterization of a breast cancer cell line derived from a germ-line BRCA1 mutation carrier. Cancer Res. 1998, 58, 3237-3242.

72. Young, R.K.; Cailleau, R.M.; Mackay, B.; Reeves, W.J. Establishment of epithelial cell line MDA-MB-157 from metastatic pleural effusion of human breast carcinoma. In Vitro 1974, 9, 239-245. [CrossRef] [PubMed]

(C) 2020 by the authors. Licensee MDPI, Basel, Switzerland. This article is an open access article distributed under the terms and conditions of the Creative Commons Attribution (CC BY) license (http://creativecommons.org/licenses/by/4.0/). 